\title{
Principio de legalidad y prevaricato
}

Alexander López-Quiroz

Magíster en Derecho Constitucional, Universidad Libre de Cali. Profesor,

Universidad del Tolima, Ibagué,

Colombia.

Correo electrónico:

alexanderlopezquiroz@yahoo.es

Recibido: 28 de abril del 2016

Aprobado: 10 de agosto del 2016

Cómo citar este artículo: Alexander LópezQuiroz. Principio de legalidad y prevaricato. DIXI 24. Octubre 2016. Pág. 25. doi: http:// dx.doi.org/10.16925/di.v18i24.1521

\section{Resumen}

Propósito: determinar si el prevaricato es posible, al no acatar lo que se ha denominado "precedente judicial" por la Corte Constitucional. Descripción: se analiza la existencia normativa del precedente judicial $y$, sobre esta base, si es procedente juzgar por prevaricato a un servidor público por alejarse de la doctrina de las altas cortes. Punto de vista: el precedente judicial o legislación judicial no es ley legítima en Colombia, no existe el prevaricato cuando un juez se aleja de las sentencias de las altas cortes. Conclusiones: desde el principio de legalidad y a través de la inducción, se logra demostrar que la Corte Constitucional carece de la competencia funcional para legislar, y al hacerlo, prevarica. El hecho de no darle poder vinculante a la doctrina de las altas cortes no se constituye en prevaricato, como lo ha afirmado la Corte Constitucional colombiana.

Palabras clave: civil law, common law, precedente judicial, prevaricato. 


\title{
The Principle of Legality and Malfeasance
}

\begin{abstract}
Purpose: To determine if malfeasance is possible when what has been called judicial precedent by the Constitutional Court of Colombia is not abided by. Methodology: This article analyzes the existing norms of judicial precedent and, on this basis, whether it is lawful to try a public servant for malfeasance for departing from the doctrine of the high courts. Viewpoint: Judicial precedent, or judicial legislation, is not legitimate law in Colombia; therefore, no malfeasance is committed when a judge departs from the rulings of the high courts. Conclusions: According to the principle of legality and through induction, it is possible to demonstrate that the Constitutional Court lacks the functional competence to legislate, and its doing so constitutes malfeasance. Failure to give binding force to the doctrine of the high courts does not constitute malfeasance, as has been affirmed by the Constitutional Court of Colombia.
\end{abstract}

Keywords: civil law, common law, judicial precedent, malfeasance

\section{Princípio de legalidade e prevaricação}

\section{Resumo}

Propósito: determinar se a prevaricação é possível, ao não atacar o que se denominou como "precedente judicial" pela Corte Constitucional. Descrição: analisa-se a existência normativa do precedente judicial e, sobre essa base, se for procedente julgar por prevaricação a um servidor público por afastar-se da doutrina das altas cortes. Ponto de vista: o precedente judicial ou legislação judicial não é lei legítima na Colômbia, não existe a prevaricação quando o juiz se afasta das sentenças das altas cortes. Conclusões: a partir do princípio de legalidade e por meio da indução, consegue-se demonstrar que a Corte Constitucional carece de competência funcional para legislar, e ao fazê-lo prevarica. O fato de não dar poder vinculante à doutrina das altas cortes não se constitui prevaricação, como afirmou a Corte Constitucional colombiana.

Palavras-chave: civil law, common law, precedente judicial, prevaricação. 


\section{INTRODUCCIÓN}

La Corte Constitucional afirma que al expedir una decisión judicial contraria a las decisiones de las altas cortes, se incurre en prevaricato. En la Sentencia C-083 de 1995, se afirmó que la doctrina de la Corte Constitucional es obligatoria y termina con la Sentencia C-335 de 2008. Así mismo, allí se afirma que se incurre en prevaricato cuando el servidor público no obedece la jurisprudencia de las altas cortes.

El tema central de este documento es determinar si la Corte Constitucional goza de competencia funcional para "legislar" y crear un tipo penal, a partir de sentencias denominadas "jurisprudencia" y/o hasta "precedente judicial”. Para ello, se demostrará si la jurisprudencia se constituye o no en norma vinculante, todo esto bajo la óptica del principio de legalidad vigente. Este es un trabajo basado en el principio de legalidad, superior, Art. 29, y en el sistema jurídico legislado. El tema se ha abordado desde la perspectiva jurídica, no sociológica ni filosófica.

En la "realidad" política1 de la sociedad del hombre, se presentan dos grandes sistemas jurídicos, a saber: el "Common law" y el "Civil law". Cada uno cuenta con un origen y características propias, lo que hace que cada uno de ellos adquiera en su desarrollo unas figuras o fenómenos jurídicos propios de cada forma o sistema jurídico.

El Common law es el sistema jurídico que se basa en la costumbre social, es un Derecho creado por los jueces a partir de la realidad social; es dúctil, cambiante con la realidad social, es garantía de una real división de poderes estatales. En este sistema juzgan los iguales, de manera que es garantía en el sentido literal de la palabra. Se caracteriza, además de lo anterior, porque la rama judicial carece de competencia funcional para derogar la ley parlamentaria: la rama judicial inaplica la ley y es el desuso lo que hace que la ley o norma pierda vigencia, con lo cual esta desaparece de la realidad social y deja de ser costumbre, ya que la costumbre es ley.

Según afirma Morineau, el sistema jurídico del Common law se construye sobre una cultura, un idioma y una forma de entender el Derecho muy diferente a la forma, el idioma y la cultura de los países latinoamericanos que, en un inicio, fuimos influidos por la legislación romano-francesa, el Código Civil, un Derecho codificado (escrito siempre) y un Consejo de Estado, entre otros.

1 Léase por "realidad política", "realidad social".
Se puede afirmar que las figuras jurídicas del Common law son eficientes, son eficaces y buscan la justicia, en el entendido de la vivencia social, esto es, lo que es común dentro de ese contexto político-jurídico. Por otra parte, en el sistema jurídico del Civil law, se entiende por justo lo que se encuentra atemperado a la ley, y esta es siempre escrita. Son equivalentes los dos sistemas jurídicos mencionados, dado lo siguiente: en el Common law la costumbre es ley, y sobre esta se juzga; en el Civil law, la ley es lo legislado y escrito, y sobre esta se juzga.

Esta forma de ver y vivir el Derecho (Common law) no es transferible, mutatis mutandis, al Derecho legislado, en el cual lo que prima o tiene más transcendencia es la ley legislada por un órgano delegado por el soberano pueblo, y por ello, la finalidad en este tipo de sistema es que la sociedad sea regulada por la ley, lo que implica que la sociedad se somete a la ley, la cual es creada o expedida por un órgano que la representa ${ }^{2}$ y que está subordinado o, mejor, cuya finalidad es la búsqueda del bien común. En el otro sistema, la sociedad en sí misma es la creadora de Derecho en su vivencia, a pesar de que también existe un órgano legislativo.

Esta sería una primera razón para no aceptar el precedente en el sistema jurídico del Civil law. De otro lado, el Civil law es el sistema jurídico que se basa en la legislación positiva, esto es, en las normas o leyes expedidas por un órgano especializado y bajo un procedimiento previamente establecido, por lo que es un sistema jurídico que solo reconoce lo "legislado" como Derecho. Se caracteriza por la codificación legislativa y, en casos de vacíos normativos, la ley permite el uso de los principios generales del Derecho como fuente normativa, ya que es la ley misma la que autoriza dicha aplicación.

El precedente judicial es una figura jurídica endémica del sistema jurídico Common law, fuente creadora del Derecho y a la vez la forma de entenderlo y aplicarlo; en otras palabras, es el reconocimiento de la costumbre como norma y las sentencias como la forma de su aplicación.

La forma de aplicación de la norma - que es esencialmente lo que le da sentido- es parte de la misma y, por ende, obligatoria (la hace eficaz). Si cada sistema jurídico ha construido de diversas maneras sus reglas y fenómenos jurídicos propios, en cada uno de ellos, en principio, y en tanto no constituyan una contradicción en sí misma al sistema mismo, las

2 Por lo menos, de manera formal, sabemos que en Colombia el interés del Congreso de la República en los últimos años ha sido el interés del ejecutivo, y no el de la sociedad en general. 
reglas y fenómenos de cada uno podrán aplicarse en el otro de los sistemas imperantes. En otras palabras, existen principios jurídicos comunes a los dos sistemas, así como existen principios y figuras jurídicas propias de cada sistema que como tal no son aplicables o transmutables de un sistema a otro (mutatis mutandis).

Desde el siglo Ixx, se estableció por el legislador colombiano lo siguiente:

Artículo $8 \mathrm{La}$ costumbre en ningún caso tiene fuerza contra la ley. No podrá alegarse desuso para su inobservancia, ni práctica alguna, por inveterada y general que sea ${ }^{3}$.

Y en la Ley 153: "Artículo 13 La costumbre siendo general y conforme con la moral cristiana, constituye derecho a falta de legislación positiva"4.

De las normas citadas se puede inferir que, solo en casos muy especiales, la costumbre es tomada como norma vinculante. De otro lado, el Código de Comercio establece en la costumbre mercantil un valor normativo bajo los siguientes requisitos:

Artículo $3 .^{\circ}$ La costumbre mercantil tendrá la misma autoridad que la ley comercial, siempre que no la contraríe manifiesta o tácitamente y que los hechos constitutivos de la misma sean públicos, uniformes y reiterados en el lugar donde hayan de cumplirse las prestaciones o surgido las relaciones que deban regularse por ella.

En defecto de costumbre local se tendrá en cuenta la general del país, siempre que reúna los requisitos exigidos en el inciso anterior ${ }^{5}$.

Esta norma confirma lo plasmado en el Código Civil - previamente citado-, de manera que la costumbre adquiere el valor de norma en las siguientes situaciones:

- En los eventos en los cuales no existe ley positiva, la costumbre mercantil en el Derecho comercial adquiere fuerza de ley bajo la condición que no sea contraria a la ley.

3 Véase Código Civil Colombiano [ccc]. Editorial Legis S.A. (2009).

4 Véase Ley 153 de 1887. Por la cual se adiciona y reforman los códigos nacionales, la ley 61 de 1886 y la 57 de 1887 . Agosto 28 de 1998. Do 7151 y 7152.

Véase Código de Comercio Colombiano [cco]. (Colombia). Junio 16 de 1971. (2009). Editorial Legis s. A.
- La costumbre mercantil sirve también, además, para determinar el sentido de las palabras o frases técnicas del comercio, así como para interpretar los actos y convenios mercantiles ${ }^{6}$.

A pesar de que la costumbre en esas situaciones se constituye en norma general y abstracta ${ }^{7}$, es decir, se vuelve ley, lo hace igual que en el Derecho civil: solo cuando existe vacío legislativo. Sin embargo, debe tenerse en cuenta que es el mismo sistema jurídico el que le otorga validez y eficacia jurídica a la costumbre.

De igual forma, se expidió por el legislador la siguiente norma:

Artículo 17. Las sentencias judiciales no tienen fuerza obligatoria sino respecto de las causas en que fueron pronunciadas. Es por tanto, prohibido a los jueces proveer en los negocios de su competencia por vía de disposición general o reglamentaria ${ }^{8}$.

Se infiere que las sentencias judiciales no pueden constituir precedente en Colombia, y mucho menos el sustento de la sentencia. El sentido de la norma es claro: se limita a las partes que participaron en el caso.

La doctrina constitucional - que es la interpretación y aplicación dada por los jueces a la Constitución Política ${ }^{9}$ - tiene un efecto con el órgano legislador; esto en el sentido que dichas funciones sirven de guía al Congreso de la República para expedir las leyes necesarias en la regulación de las relaciones personales en sociedad.

Es evidente que el marco normativo vigente no establece un valor normativo en la costumbre de manera general, sino excepcional: las sentencias judiciales solo rigen entre partes, la jurisprudencia constituye doctrina probable, los jueces podrán aplicarla en casos análogos ${ }^{10}$ y la doctrina constitucional sirve como guía para expedir las leyes.

Este es el marco normativo y que en parte fueron demandados ${ }^{11}$ en control de abstracto consti-

\footnotetext{
$6 \quad$ Id. Art. 5.

7 En el área mercantil, en la zona o territorio de la costumbre, que debe ser "reseñada"; aquella si es una norma con más alcance territorial.

8 Véase Código Civil Colombiano [CCC], supra, nota 4.

9 Id. Artículo 26.

10 Véase Ley 169 de 1896. Sobre reformas judiciales. Enero 14 de 1897. Do 10235 .

11 La Corte Constitucional lo declaró exequible, si se entiende que moral cristiana es la costumbre general. Cf. Corte Constitucional de Colombia. Sentencia C-254. (mp Fabio Morón Díaz, Junio 7 de 1995). Cf. Ley 153 de 1883, supra, nota 5. Artículo 13.
} 
tucionalidad y la $\mathrm{H}$ Corte Constitucional, cuya decisión de fondo fue declarar la exequibilidad, por ende, son normas que rigen, porque tienen vigencia.

Si estas normas se encuentran vigentes son de obligatorio acatamiento ${ }^{12}$, y como tal vinculan a todos sin excepción en el territorio colombiano. Lo extraño es que a pesar de la vigencia de estas leyes, su contenido fue desconocido por la Corte Constitucional de manera fáctica. Así, se presenta una clara contradicción que conlleva a una aporía, tal como es el hecho de declarar judicialmente que rige el principio de legalidad, y a pesar de dicha afirmación, no aplica lo que dice la ley, sino lo que la propia Corte Constitucional afirma que dice la ley.

La Corte Constitucional declara exequibles dichas normas, pero las deroga con sus sentencias erga omnes, con sus sentencias "precedente".

$\mathrm{Al}$ ser la Constitución Política norma de normas, se afirmó por el constituyente - y lo afirma la Constitución Política-, que la primera ley es la Carta Magna y, por ende, al ser la primera ley, es aplicable sin necesidad de desarrollo legislativo por parte del Congreso. Lo anterior también implica la obediencia o sometimiento de todos - sin excepción- a sus normas.

La Corte Constitucional, en cumplimiento de su función constitucional, ha manifestado que, una vez las palabras de la primera ley dicen lo que dicen, no dicen eso, sino lo que la Corte Constitucional dice que dice ${ }^{13}$.

Al decir, decir a la primera ley lo que no dice ${ }^{14}$, la Corte Constitucional, primero, incumple la Constitución Política; segundo, modifica el sistema jurídico y rompe el principio de división de poderes, ya que legisla a través de sus sentencias.

Cuando la Corte Constitucional afirma que su sentencia es vinculante, deroga de hecho o de oficio (sin acción pública) el Artículo 17 del Código Civil. De nuevo, surge la esquizofrenia judicial: a fin de proteger a la Constitución Política de otros, el guardián la viola, la incumple, la modifica, la inaplica y la deroga. Las sentencias no son vinculantes ordenó el legislador; la Corte Constitucional dice sí lo son, por esto se afirma que de hecho deroga la norma vigente,

12 Véase Código Civil Colombiano [Ccc], supra, nota 4. Artículos 3 y 4.

13 La palabra deja de tener el significado social y pasa a significar lo que dice la Corte Constitucional que significa. La Constitución Política y la ley no se rigen por la palabra escrita, sino por el significante que le da la iluminada y bendecida Corte Constitucional.

14 Logra este cometido al cambiar el significado de las palabras: ley por ordenamiento jurídico, costumbre cristiana por costumbre social, entre otras. sin acción pública de control abstracto de constitucionalidad, es decir, obra de oficio, competencia funcional de la que carece.

\section{Desarrollo}

\section{A. Colombia Civil Law o Common Law}

El sistema jurídico colombiano se puede clasificar como continental, o Derecho escrito (o positivo), es decir, se basa en normas expedidas por órgano especial, denominado en Colombia "rama legislativa" o Congreso de la República. Esto fue reconocido por la Asamblea Nacional Constituyente, Artículo 150: no se puede desconocer que existen decretos con fuerza de ley y decretos reglamentarios que también tienen fuerza vinculante, es decir, son creadoras de derechos, deberes y obligaciones.

El denominado ius positivismo, sistema o método de interpretación jurídica que propende al reconocimiento de los valores y principios establecidos en y por las propias normas jurídicas, acepta como vinculante solo el marco jurídico expedido válidamente; esto es, por el órgano competente, el cual cumpla con el procedimiento establecido para ello, aunado a que sea aplicable en el contexto social para el cual fue expedido ${ }^{15}$. Este sistema permite abordar con criterios "objetivos" la finalidad de la ley o el marco jurídico en general ${ }^{16}$, y por ende, también el reconocimiento a la Constitución Política como norma superior y la protección de la misma ${ }^{17}$.

15 Véase Hans Kelsen. Teoría pura del Derecho. Editorial Porrúa. (2009).

16 No lo hace de manera completa. Como todo, es insuficiente frente a una realidad cambiante y cada vez más compleja. Sin embargo, sí es una manera más objetiva de ver el Derecho, en tanto que depende de la norma, no de la reacción o de los valores de quien debe ser objetivo, autónomo e independiente al resolver el caso.

17 Mediante el formalismo jurídico, el jurista puede defender la existencia de un método propio, neutral, capaz de dar una solución justa usando principios universales o universalizables, idóneos para legitimar la decisión jurídica por si misma. Véase Pierre Bourdieu y Gunther Teubner. La Racionalidad jurídica en crisis. Editorial Siglo del Hombre, Facultad de Derecho de la Universidad de los Andes, Ediciones UnIANDES, Instituto PENSAR. (2000). Pág 72.

${ }^{(* * *)}$ En lo que se refiere al tema aquí propuesto, que es el juicio constitucional a la ley, objeto de control. La moral es un elemento del derecho, especialmente del derecho relacionado con los $\mathrm{DDHH}$, la relación con las otras áreas del derecho es menos directa. La excepción a la aplicación de las normas morales en el derecho se da en el derecho disciplinario, en tanto que se trata del cumplimiento de deberes, el deber es axiológico. 
La Constitución Política de Colombia, en el Art 230 , establece el sistema ius positivista ${ }^{18}$, al establecer que los jueces para proferir sus providencias se encuentran exclusivamente sometidos al imperio de la Constitución y la ley ${ }^{19}$; los demás son criterios auxiliares en casos de vacíos jurídicos.

Al realizar una interpretación normativa de cualquier nivel, se debe tomar en consideración el marco normativo en sí mismo, es decir, no son aplicables criterios subjetivos que rayan con la injusticia, entendida esta como la inaplicación del Derecho ${ }^{20}$. Es importante conocer y saber con certeza si el marco jurídico en el cual se desenvuelve el operador jurídico es un sistema ius natural o ius positivista, en aras de establecer los criterios propios de cada sistema, los cuales se deberán tener en cuenta al momento de resolver un conflicto surgido en las relaciones sociales.

Cuando la Corte Constitucional realiza la revisión de constitucionalidad de una norma, y realiza el control propuesto bajo un análisis o método de comparación de los aplicados en otras latitudes - como si las consideraciones sociales, económicas o jurídicas fueran las mismas, es decir, no toma en consideración la realidad histórica pasada ni la del momento en el cual la corte extranjera tomó esa (o una) decisión-; lo hace de tal manera que se entienda como esa manera de interpretar la Constitución Política es aplicable en nuestro sistema jurídico mutatis mutandis, de modo que genera un conflicto jurídico que trasciende a lo político. Esto en razón a que esa importación doctrinal de figuras jurídicas - teórica y conceptualmente- no es procedente en un sistema jurídico que se rige por los principios y características del llamado Derecho continental o francés (Civil law), ya que muchas de ellas (las copiadas de otras latitudes)

18 Al utilizar sistema gramatical e histórico, se interpreta que los constituyentes no establecieron la palabra ley como norma o regla, sino el sentido jurídico político otorgado desde la Revolución francesa, el cual implica soberanía, división de poderes, principio de legalidad. No se le dio el alcance de "norma", ni de "marco jurídico", ni ningún otro. Cuando la Constitución dice "Ley", se debe entender eso: "ley", no otra cosa. Al ordenar que el juez se limita con la Constitución y la ley, se acepta un sistema continental de Derecho o Civil law.

19 En la afirmación, "los jueces, en sus providencias, sólo están sometidos al imperio de la ley", es evidente el querer del constituyente, que en el momento de decidir o dirimir cualquier controversia se sometan a lo ordenado en la ley, es decir, separa claramente los valores morales del Derecho.

20 Derecho aceptado como el marco jurídico válido y eficaz. E Derecho busca la justicia, por ello se ha aceptado que generalmente la ley es justa, y la ley injusta, al ser ilegitima, no debe ser obedecida. Criterio sociológico de interpretación. son inherentes al sistema anglosajón (Common law), como, por ejemplo, el precedente judicial.

Aceptar ese tipo de judicialización es lo que produce que sea válido afirmar que un órgano constitucional deja de lado el objeto de su función y va más allá, en aras de buscar una concretización de los derechos fundamentales. Situación que en un país con tanta desigualdad social se acepta, es decir, se legitima ese activismo judicial a través de la acción de tutela. Sin embargo, dicho procedimiento no puede validarse para el ejercicio de control abstracto de constitucionalidad de la ley, ya que se trata de un análisis de la ley frente a la Constitución Política, es decir, norma contra norma, procedimiento que debería concluir en una sentencia exequible o no.

Si la judicialización constitucional de la ley se ejerce de forma axiológica dentro de un sistema como el Civil law, entonces se está ante un procedimiento que acarrea una clara y evidente inseguridad jurídica, en tanto que la unificación jurisprudencial no dependerá del marco jurídico, sino de los principios y valores morales de quien interpreta las normas jurídicas objeto de control judicial. Todo supuestamente en aras de garantizar los Derechos Humanos (DDHH), de una parte, y de la otra preservar la Constitución Política.

En el Derecho anglosajón, el juez carece de competencia para anular una ley, es decir, se inaplica pero no se deroga. Esto genera un criterio diferenciador de las formas de las figuras jurídicas propias de ese sistema jurídico muy diferente al continental, el cual sí permite la declaración de inexequibilidad de normas (cuyo efecto es la derogación de normas por parte de la rama judicial); esto es, el exterminio de la ley por órgano diferente al legislador: allá Parlamento, acá Congreso.

El precedente judicial anglosajón se sustenta en la costumbre común de una comunidad. En nuestra formación jurídico-política, es imperioso defender la Constitución Política de cualquier posibilidad que llegue a ser conculcada, por cualquier autoridad o cualquier persona, y con el fin de lograr el cumplimiento del mandato consagrado en el Artículo 4, esto es, que la Constitución es la norma de normas.

En la norma de normas, se manifiesta que la jurisprudencia es criterio auxiliar de los jueces ${ }^{21}$. La Corte Constitucional ha dicho que la jurisprudencia

21 Véase Constitución Política de Colombia [Const]. Art. 230. Julio 7 de 1991 (Colombia).

$\left.{ }^{\star}\right)$ En el sentido del soporte normativo constitucional del precedente. 
es vinculante, esto es, es una norma, con lo cual la Corte Constitucional creó una norma positiva.

La Corte Constitucional ha venido construyendo o creando de hecho el precedente judicial, a sabiendas que dicha figura jurídica se constituye o tiene los mismos efectos que una ley, esto es, tiene fuerza vinculante erga omnes.

Como se sabe, teóricamente el sistema del Civil law no es compatible con el precedente judicial, en tanto que es la ley expedida bajo el procedimiento y por la autoridad competente la que tiene fuerza vinculante. Además, se deberá tener en cuenta que nuestro sistema jurídico, en el control de constitucionalidad, se regula por un control difuso, lo que se demuestra con la existencia de la excepción de constitucionalidad (con la acción de nulidad de los actos administrativos, y por la acción de tutela).

Las normas constitucionales y los tratados internacionales sobre DDHH constituyen el marco jurídico superior, es decir, las leyes no podrán contradecir a aquellas, so pena de perder fuerza vinculante.

Se constituye como norma en el actual sistema jurídico aquella que es expedida por el órgano constitucional competente, cumpliendo los requisitos de forma o procedimiento establecidos para ello, esto es, todas las normas que obligan o las que son objeto de coacción para su cumplimiento, bien sea por las autoridades, o bien por los asociados. Lo demás no se clasifica como norma en la concepción del Civil law. Uno de los principales exponentes de estas ideas es Hans Kelsen, quien al respecto afirma lo siguiente:

El derecho positivo, sistema jurídico, que propende por reconocer los valores y principios establecidos por las propias normas jurídicas, reconoce como vinculante el marco jurídico expedido válidamente, esto es, por el órgano competente y que cumpla con el procedimiento establecido para ello, aunado a que sea aplicable en el contexto social para el cual fue expedido $^{22}$.

En el caso colombiano, el Congreso de la República es quien tiene la competencia de expedir normas, según expreso mandato de la Constitución Política en los Artículos 114 y 150, lo cual es una afirmación apodíctica. Quién puede expedir normas o leyes validas en Colombia es el Congreso de la República, respuesta que se asemeja a la dada por Carl Schmitt ${ }^{23}$.

22 Véase Hans Kelsen. Teoría PURA del Derecho, supra, nota 17. Pág. 7.

23 Véase Carl Schmitt. LA Defensa de la Constitución. ESTUDIO ACERCA DE LAS DIVERSAS ESPECIES Y POSIBILIDADES DE
Quien puede interpretar las leyes en Colombia es el Congreso de la República, sin embargo, la Corte Constitucional, en la Sentencia C-037 de 1996, afirmó: no solo el Congreso de la República interpreta por vía de autoridad, ya que dicha afirmación es válida únicamente en lo que se relaciona con la ley, pero no en el tema constitucional ${ }^{24}$.

La interpretación del Congreso se debe plasmar en otra ley, mientras que la interpretación de la Corte Constitucional en los procesos de control abstracto de constitucionalidad debe concluir en exequible o no.

El problema surge cuando los magistrados de la Corte Constitucional afirman y ordenan que dicha interpretación de la ley sea vinculante; se afirma que la razón de la sentencia que es directamente relacionada con aquella decisión también tiene efectos vinculantes, (ratio discedendi), y ponen como argumento norma derogada, la cual permitía que en casos que la sentencia fuera contraria a la jurisprudencia, este constituye razón suficiente como causal de casación.

La Constitución Política, al determinar la competencia funcional de la Corte Constitucional, afirma lo siguiente:

A la Corte Constitucional se le confía la guarda de la integridad y supremacía de la Constitución, en los estrictos y precisos términos de este artículo. Con tal fin, cumplirá las siguientes funciones:

A pesar de que la Carta no establece de manera taxativa o precisa la interpretación de las leyes, a fin de decidir si una norma es contraria o no a la Carta fundamental, la Corte debe realizar un ejercicio interpretativo a fin de determinar el alcance de la norma demandada, es decir, por la naturaleza de su función en sí debe interpretar las leyes.

Frente a la pregunta de quién puede interpretar las leyes, en principio la respuesta es la misma: el Congreso de la República. Sin embargo, la Corte Constitucional tiene la competencia de velar por la protección de la Constitución Política, juzgando que leyes le son contrarias. En estos casos, esta institución pública judicial realiza una interpretación

SALVAGUARDA DE LA Constitución. (1931). Editorial Labor s.A. ${ }^{*}$ ) Carácter que le otorga la Constitución Política, es decir, no tiene competencia política, ni legislativa ni interpretativa, es un operador jurídico más, sólo que su función es velar por que el legislador no viole la Constitución al expedir leyes. Art. 113 C.P.

24 Cf. Corte Constitucional. Sentencia C-037 DE 1996 (MP Vladimiro Naranjo Mesa, mayo 2 de 1996). 
de la Constitución en la ley objeto de demanda, y de manera obvia debe interpretar la ley frente a las normas y principios constitucionales. Así, la interpretación de la ley, aparentemente, puede darse en dos situaciones: por el Congreso de la República, sobre lo que no hay discusión alguna; $y$, por parte de la Corte Constitucional, con el propósito de decidir si es acorde o no con la Constitución Política.

A pesar de que la Carta no establece de manera taxativa o precisa la interpretación de las leyes como función de la Corte Constitucional, para decidir si una norma es contraria o no la Carta fundamental, la Corte Constitucional debe realizar un ejercicio interpretativo que permita determinar el alcance de la norma demandada, es decir, por la función en sí debe interpretar las leyes.

Ahora bien, ¿esa interpretación de las leyes realizada por la Corte Constitucional es vinculante? Al respecto la Corte Constitucional ha evolucionado manifestando y sustentando, en un principio, que las sentencias proferidas por ella no eran vinculantes. Sin embargo, posteriormente fue cambiando su posición y terminó por argumentar que no acoger la interpretación dada a una norma por la Corte Constitucional, o alejarse de los pronunciamientos de las altas cortes, o de la jurisprudencia, genera prevaricato.

Las siguientes sentencias de la Corte Constitucional se han referido al precedente, esto sin significar que sean todas referentes al tema: C-038 1995; C-447 1997; C-309 1997; C-392 2000; C-1064 2001; C-1216 2001; C-1195 2001; A-138 2008; C-25 2001; C-127 2002; C-836 2002; C-266 2002; C-1075 2002; C-228 2002; C-250 2003; C-254 2003; C-451 2003; C-565 2000; C-424 2004; C-618 2004; C-931 2004; C-1266 2005; C-424 2006; C-209 2007; C-781 2007; C-335 2008; C-1063 2008; C-377 2008; C-1063 2008; y C-841 2008.

En términos de Alexi:

Por principio de legalidad no podemos entender simplemente el cumplimiento de los principios constitucionales (...) el Estado de derecho es impensable a partir exclusivamente de principios generales y valoraciones constitucionales, pues es indispensable un desarrollo normativo de rango inferior y sistemático, que resuelva los conflictos entre principios y valores de orden superior. Además, solo la interpretación valorista de la Constitución aniquila la legalidad a cambio del decisionismo del juez ${ }^{25}$.

25 Véase Alexi Robert. Teoría DE LA Argumentación JurídicA. Editorial. (Fecha). Pág.
Y en otro de sus textos asegura: "El principio de la legalidad significa pues la obediencia a toda norma del sistema jerárquico que no viole la Constitución, es decir de aquella norma que establezca la restricción legítima de un principio a favor de otro" 26.

El texto anterior nos remite al tema de los derechos fundamentales, en los cuales las características pro homine tienen una carga muy superior, en tanto que se trata de aplicar e interpretar los derechos legales bajo la óptica de las garantías supralegales, del derecho a la vida, a la salud, a educación y un ambiente sano, entre otros. En estos derechos el tradicional principio de legalidad ha perdido identidad y aplicabilidad, en razón a que es la propia Constitución la que señala los principios y finalidades del Estado colombiano. Si estos se manifiestan y a la vez se constituyen en la garantía de los derechos fundamentales de las personas la interpretación legal y el mismo principio de legalidad, para esta clase de normas no son válidas las reglas de interpretación y aplicación del Estado de Derecho.

En el Estado Social de Derecho, los derechos fundamentales y sociales adquieren esa trascendencia y, por lo mismo, se exige su materialización dentro de los límites del propio Estado, a fin de alcanzar esta realidad objetiva y subjetiva. Objetiva, en tanto que se encuentra plasmada o consagrada en la norma de normas; subjetiva porque la Constitución Política es la garantía de la relación entre los asociados y el Estado. Lo objetivo se logró al establecer como fin del Estado la garantía y efectivización de los derechos fundamentales. Lo subjetivo depende de casos particulares y, en estos casos especialísimos, es aplicable lo manifestado anteriormente de Robert Alexi, en el sentido que la Carta es un tejido de principios y valores y, como tal, la aplicación e interpretación de la misma adquiere un contexto totalmente diferente a las normas tradicionales.

$\mathrm{Al}$ respecto, la Corte Constitucional -frente a sentencias de control abstracto de constitucionalidad-, ha pasado de un criterio que acepta el imperio de la carta, y declaró que la jurisprudencia es un criterio auxiliar; luego, dijo que la jurisprudencia es vinculante, y terminó afirmando que no solo es vinculante la parte resolutiva del fallo judicial, sino la parte considerativa que estuviere directamente relacionada con el fallo expedido, es decir, la "argumentación" que sustenta la sentencia (lo denominado ratio decidendi) ${ }^{27}$. En este sentido, ¿cuál ha sido el criterio

\footnotetext{
26 Id. Pág.

27 Cf. Corte Constitucional, supra, nota 27.
} 
de la Corte Constitucional en las diferentes etapas de la evolución en la construcción del precedente?

En la Sentencia T-260 de 1995, la Corte comenzó a hacer reconocer el carácter vinculante de sus fallos proferidos en sede de amparo, sopesando el principio de autonomía judicial y el derecho que tienen los ciudadanos a ser juzgados de manera igual.

En últimas, la Constitución Política es una sola, y el contenido de sus preceptos no puede variar indefinidamente según el criterio de cada uno de los jueces llamados a definir los conflictos surgidos en relación con los derechos fundamentales ${ }^{28}$. En la Sentencia C-083 de 1995, se afirmó que la doctrina de la Corte Constitucional es obligatoria. Posteriormente, en la Sentencia C-252 de 2001, la Corte reiteró su postura en cuanto al carácter vinculante de presentar los fallos de tutela, los cuales trascienden la resolución del caso concreto, contrariando un decreto ley y la ley marco de la administración de justicia:

Aun cuando los efectos jurídicos emanados de la parte resolutiva de un fallo de revisión solamente obligan a las partes, el valor doctrinal de los fundamentos jurídicos o consideraciones de estas sentencias trasciende el asunto revisado. La interpretación constitucional fijada por la Corte determina el contenido y alcance de los preceptos de la Carta y hace parte, a su vez, del "imperio de la ley" a que están sujetos los jueces según lo dispuesto en el artículo 230 de la Constitución ${ }^{29}$

Así mismo, en la Sentencia C-335 de 2008 se afirmó que se incurre en prevaricato cuando el servidor público no obedece la jurisprudencia de las altas cortes. Por otra parte, en la Sentencia C-252 de 2001 se lee:

En Colombia los jueces tienen una obligación positiva de atender los materiales legitimados en los cuales se expresa el derecho. Y uno de esos materiales, es, ahora, la jurisprudencia que se viene a agregar a los ya tradicionales (Constitución y ley) ${ }^{30}$.

Frente a las "órdenes" expedidas por la Corte Constitucional, en las que afirma esta que las sentencias expedidas en el ejercicio de control abstracto de

28 Véase Corte Constitucional de Colombia. Sentencia C-335 DE 2008 (MP, Humberto Antonio Sierra Porto, Abril 16 del 2008).

29 Véase Constitución Política de Colombia [Const.], supra, nota 23. Art. 230.

30 Véase Corte Constitucional de Colombia. Sentencia C-252 DE 2001 (MP, Carlos Gaviria Díaz, febrero 28 del 2001). constitucionalidad son vinculantes, no se comparte dicha afirmación, en tanto que se realiza por fuera de lo establecido en la Constitución Política. En este orden de ideas, no hay un solo texto constitucional, hay dos: el expedido por la Asamblea Nacional Constituyente, y el creado por la Corte Constitucional.

Colombia tiene un sistema jurídico positivo o continental (o Civil law), en el que la fuerza vinculante la tiene la ley expedida por el órgano competente. Al cumplir el procedimiento legal para ello, es decir, el efectuado por el Congreso de la República, las demás normas no tienen fuerza vinculante y la jurisprudencia es un criterio auxiliar de interpretación, no es ley.

\section{B. Principio de Legalidad}

El Estado moderno se caracteriza por realizar un reconocimiento expreso de los denominados derechos naturales del hombre:

Las revoluciones del siglo XIX, pusieron énfasis especial en: la libertad, la propiedad y el principio de legalidad; respecto de éste (legalidad) se estableció en la parte continental Europea, que la ley siempre fuese escrita y elaborada por el pueblo o su representante, esto es por el legislador, con el fin de evitar la arbitrariedad de la autoridad estatal, práctica acogida en nuestro parte del continente Americano ${ }^{31}$.

Este principio se plasmó en la Declaración del Hombre y el Ciudadano, en el Art. 16, y es en esta época histórica en la que el legislador es la autoridad que representa, no solo al Estado, sino a los asociados $^{32}$, en tanto que a través de la ley es que se garantizan los derechos naturales del hombre, los cuales se encuentran plasmados en la mayoría de constituciones políticas de los Estados del mundo contemporáneo.

La Constitución Política colombiana no es ajena a esta manera de plasmar el Derecho, por ello el art. 5 , en concordancia con el art. 29, dice que se reconocen los derechos naturales del hombre. Se entiende por derechos inalienables los DDHH plasmados en la Constitución como derechos fundamentales. El principio de legalidad de igual manera es reconocido,

31 Se podría afirmar que el derecho es la ley, en tanto que es la ley la que sobre la base de un reconocimiento de derechos naturales los materializa. El Derecho existe pero se "hace", (es) lo que es a través de la ley. Sin ley no hay Derecho. Para los anglosajones la realidad social es la ley, por ende la ley es real.

32 En los Estados continentales e hispanoamericanos. 
como se dijo, por la Revolución francesa. En el ordenamiento colombiano, el Artículo 29 reconoce el principio de legalidad como fundamental y como DDHH en los tratados internacionales, es decir, goza de superior jerarquía vinculante, tal como el Artículo 93 superior lo establece.

Dado lo anterior, muchos escritores denominan esta forma como el principio de legalidad "primacía de la ley", y lo definen como "el marco jurídico cuya finalidad es la de garantizar la libertad, igualdad y la seguridad individual de las personas"; en todo caso, evitar la tiranía (garantizar, proteger los DDHH).

De igual forma, en aras de proteger la libertad, aun del propio Estado liberal se decidió en la Constitución Política, lo cual para la validez de la ley se debería cumplir con un procedimiento por parte del órgano delegado a fin de cumplir con esa función legislativa. Así, pues, para que la ley sea válida, debe cumplir con unos requisitos de procedimiento y de competencia; sí se cumplen, se entiende que la ley es legítima.

Expedida la ley así (por órgano competente, que sea escrita y pública), permite que todos conozcan con anticipación los límites de la protección, o la consecuencia jurídica de sus actos, lo que conlleva a garantizar sus derechos, en especial del ejercicio arbitrario del poder punitivo del Estado.

Se ha aceptado pedagógicamente que a partir de la Revolución francesa se presenta la división de poderes y la existencia de una Constitución (que debe ser siempre escrita, según dicha declaración), la cual es la norma superior y en la que se establecen unas competencias funcionales a los diferentes órganos estatales, así como algunos procedimientos, como, por ejemplo, el determinado para la expedición de las leyes, administrar justicia o lograr la convivencia pacífica, entre otros.

En el caso de Colombia, cuya decisión política de 1991 fue la de transformarse de Estado de Derecho a un Estado Social de Derecho, y lo consagró en el preámbulo y Artículo $1^{\circ}$ de la constitución política, en los Artículos 29 y 122 se concreta el principio de legalidad. Al respecto, la Corte Constitucional afirma lo siguiente:

La construcción jurídica y política del Estado Social de Derecho descansa en el principio de legalidad [cursivas añadidas], que conlleva no sólo a que toda la actuación de los órganos del poder público se someta a la Constitución y a las leyes, sino también a la necesidad de que el ordenamiento positivo instituya toda una gama de controles políticos y jurídicos para sancionar las actuaciones que se desvíen de los parámetros normativos a que están sometidas ${ }^{33}$.

Colombia se ha caracterizado por ser un país con una división de poderes y un régimen presidencialista fuerte, lo cual, en combinación o complemento con otros elementos constitutivos de la democracia, permiten inferir la existencia de una, entendida como proceso y mecanismo: existencia de elecciones periódicas, voto universal, voto directo. En la medida en que esto ha se ha "cumplido" desde principios del siglo $\mathrm{xx}$, se puede afirmar que Colombia cumple con los requisitos para ser un país democrático en sentido formal.

Aceptado lo anterior, y conociendo que la democracia implica además el reconocimiento y la práctica de los pesos y contrapesos, lo que en principio se denominó división de poderes (reconocido así en la Constitución Política, Artículos 113 al 117), se establecen las ramas del poder público: competencia del Congreso de la República; Presidente de la República es jefe de Estado, jefe del Gobierno y suprema autoridad administrativa; la Corte Constitucional, la Corte Suprema de Justicia, el Consejo de Estado, el Consejo Superior de la Judicatura, la Fiscalía General de la Nación, los tribunales y los jueces, administran justicia. También lo hace la Justicia Penal Militar, el Ministerio Público y la Contraloría General de la República que son órganos de control. Cabe resaltar que en el Estado Social de Derecho se conservan los principios del Estado de Derecho, esto es, en Colombia todavía rigen principios de división de poderes y el principio de legalidad.

Uno de los que han sustentado y defendido la necesidad de la división de poderes como necesario para evitar la tiranía es Montesquieu ${ }^{34}$.

33 Véase Corte Constitucional de Colombia. Sentencia C-246 DE 2006 (MP Rodrigo Escobar Gil, mayo 29 del 2009).

34 "Cuando el poder legislativo y el poder ejecutivo se reúnen en la misma persona o el mismo cuerpo, no hay libertad; falta la confianza, porque puede tenerse que el monarca o el senado hagan leyes tiránicas y las ejecuten ellos mismos tiránicamente No hay libertad si el poder de juzgar no está bien deslindado del poder legislativo y del poder ejecutivo. Si no está separado del poder legislativo, se podría disponer arbitrariamente de la libertad y la vida de los ciudadanos; como que el juez sería legislador. Si no está separado del poder ejecutivo, el juez podría tener la fuerza de un opresor. Todo se habría perdido si el mismo hombre, la misma corporación de próceres, la misma asamblea del pueblo ejerciera los tres poderes: el de dictar las leyes, el de ejecutar las resoluciones públicas y el de juzgar los delitos o los pleitos entre particulares. Pero si los tribunales no deben ser fijos, sí deben serlo las sentencias, hasta el punto que deben corresponder siempre al texto expreso de la ley (...) Puesto que en un Estado libre, todo hombre, considerado como poseedor de un alma libre, debe gobernarse por sí mismo, sería 
El profesor Wilson Herrera Llanos, sobre la evolución de la división de poderes o ramas u órganos de los poderes públicos, afirma:

El reconocimiento del carácter unitario de la actividad estatal y de su expresión en funciones, ramas u órganos acabó desde hace tiempo con la gran importancia doctrinaria de la división tripartita de los poderes públicos.

Fue en la Reforma Constitucional de 1936 cuando por primera vez se cambió la denominación de «poderes» por la de «órganos» y se precisó que éstos tenían funciones separadas pero las ejercían mediante una colaboración armónica entre ellas para lograr los fines del Estado, y en la de 1945 se sustituyó tal nominación por la de «ramas».

Como la Carta de 1991 se resiste a descartar totalmente la tridivisión de las funciones estatales, aunque sin dejar de advertir, en acatamiento del moderno criterio sobre las mismas, que ellas son amplísimas y diversas, autónomas e independientes, pero integradas coherentemente en aras de la función primordial del Estado, nos sentimos obligados a referimos someramente al asunto de la tridivisión.

En contra del criterio de muchos, creemos que los antecedentes más importantes del tema de la diversificación de las funciones estatales se encuentran definidos no exactamente en la Teoría montesquiana de la Tridivisión de los Poderes, que supuestamente explicó a través de la historia que la única forma de limitar y controlar el poder era mediante su repartición en tres expresiones del mismo: el poder legislar, el poder administrar y el poder resolver los conflictos.

Es harto conocido que desde la antigüedad ya el problema del ejercicio concentrado o monopólico del poder fue objeto de variadas confrontaciones ideológicas, y son muchos los autores que citan, en tal dirección, los análisis de Aristóteles en su obra $L a$ Política, donde se indica que sólo es bien organizado aquel Estado que separa sus tres partes o elementos representativos, sin mencionar, además, el Ensayo sobre el Gobierno Civil de 1690, de John Locke, en el que se censuraba la falta de participación en los poderes legislativos y ejecutivos, concentrados en cabeza del

preciso que el pueblo en cuerpo desempeñara el poder legislativo. Pero como esto es imposible en los grandes Estados, y como está sujeto a mil inconvenientes en los pequeños, el pueblo deberá realizar por medio de sus representantes lo que no puede hacer por sí mismo". Véase Barón de Montesquieu. Del espíritu de LAS LEyes. Editorial Tecnos S. A. (1985). Pág. 109. príncipe absoluto, y la ausencia de juez que decidiera con justicia e imparcialidad ${ }^{35}$.

De lo anterior, se colige que la división de los poderes públicos del Estado es garantía de la democracia, según se indica y se acepta pacíficamente por la mayoría. La Constitución Política, en el Artículo 122, siguiendo la misma línea filosófica-política, de la necesaria división de poderes y por ende, de competencias propias de cada órgano o parte estatal.

Se colige de esta norma (la cual es un imperativo, en el sentido que se debe cumplir), cómo la Constitución estableció unas funciones propias para cada órgano del Estado (también conocidas como competencias funcionales), para cada una de las ramas del poder público existentes en Colombia, señaladas en la propia Constitución: en los Artículos 150, 151 y 152 para el Congreso; Artículos 189, 200 y 201; para la Jurisdicción ordinaria, art. 235; jurisdicción contenciosa art. 237; y para jurisdicción Constitucional, art. 241.

Lo anterior, además de determinar la competencia funcional de las diferentes autoridades estatales, también enmarca el principio de legalidad que todavía debería ${ }^{36}$ regir en Colombia, según lo expresa el Art. 29 superior.

La Corte Constitucional sobre el principio de legalidad dijo que este se configura como un elemento esencial del Estado de Derecho, de forma tal que es presupuesto de los otros elementos que lo integran. Este principio surge debido a la confluencia de dos postulados básicos de la ideología liberal: de una parte, la intención de establecer un gobierno de leyes, no de hombres (governmet of laws, not of men), esto es, "un sistema de gobierno que rechace las decisiones subjetivas y arbitrarias del monarca por un régimen de dominación objetiva, igualitaria y previsible, basado en normas generales". De otra, el postulado de la ley como expresión de la soberanía popular, el principio democrático según el cual la soberanía está en cabeza del pueblo y se expresa mediante la decisión de sus representantes, en la ley ${ }^{37}$.

En fin, la jurisprudencia sigue siendo por mandato expreso de la Constitución Política un criterio

35 Véase Wilson Herrera Llanos. La rama legislativa del poder público en Colombia. Revista DE DERECHO 20. 2003. Págs. 363-406. 36 Debería, desde la óptica y la intención de este trabajo, que es demostrar el inicio del fin de la división de poderes.

$37\left(^{*}\right.$ Norma jurídico-política la primera, la segunda de origen delegada del constituyente o soberano en el Congreso de la República, que debe cumplir requisitos establecidos en la Constitución.

Véase Corte Constitucional de Colombia, supra, nota 31. 
auxiliar para los jueces en la aplicación de la norma de normas y de la ley.

\section{Precedente judicial}

Desde hace algún tiempo para acá se viene presentando un fenómeno desconocido en el sistema jurídico de Colombia: se ha denominado "la legislación judicial”. Son aquellas decisiones de la Corte Constitucional, denominadas "sentencias aditivas y sustitutivas". En este tipo de sentencias la Corte Constitucional esgrime el argumento y, como argumento, la coordinación y complementariedad entre los diferentes órganos del Estado, con el propósito de justificar o adherir a ese tipo de legislación a los diversos estamentos sociales, es decir, convence, mas no demuestra. Así, se deduce de esa clase de sentencias que efectivamente existe un nuevo órgano legislador en Colombia; esta legislación no es legítima, en tanto que no se encuentra delegada ni regulada por la Constitución Política.

En Colombia, en conformidad con la Constitución Política, cuentan con función legisladora dos autoridades, a saber: la legisladora, y la ejecutiva en unos eventos específicos y desarrollados por la propia $\mathrm{Carta}^{38}$. De lo anterior se colige que la expedición de normas generales y abstractas se encuentra en cabeza del Congreso de la República, y excepcionalmente en cabeza de la rama ejecutiva.

A la rama judicial del poder público se le otorga la competencia funcional de decidir en Derecho el reconocimiento de los derechos de los asociados. Esto es, la rama judicial no crea ni expide legislación general y abstracta, reconoce el Derecho.

A este reconocimiento se le dice que es la creación de Derecho en aquellos casos que el juez debe fallar en aplicación de vacío normativo. Afirmación que no es cierta, pues la legislación ha previsto estos casos y para ello autoriza el uso de la analogía y, cuando no sea suficiente, el uso de los principios generales del Derecho y la equidad. Es evidente que los principios generales del Derecho son parte esencial del mismo

38 "Artículo 114: Corresponde al Congreso de la República reformar la Constitución, hacer las leyes y ejercer control político sobre el Gobierno y la administración. Artículo 150: Corresponde al Congreso hacer las leyes. Numeral 10. Revestir, hasta por seis meses, al Presidente de la República de precisas facultades extraordinarias, para expedir normas con fuerza de ley cuando la necesidad lo exija o la conveniencia pública lo aconseje. Véase también artículos 212, 213 y 215 Superior". Cf. Constitución Política de Colombia, supra, nota 23. $y$, como tal, el juez aplica también en estos casos el Derecho mismo, no lo crea.

Los jueces son los que hacen posible, de una u otra forma, que la vida en sociedad sea una realidad. Sin embargo, entregar las facultades legislativas a quien debe utilizar el fruto de esa competencia, constituye una acumulación de funciones que niegan la base de lo estructurado por la revolución burguesa.

La democracia depende, en parte, de lograr mantener la autonomía e independencia entre los poderes públicos, sin dejar de lado su coordinación y colaboración. Los jueces, según los expresos y claros mandatos de la Constitución Política, no se encuentran facultados para legislar ${ }^{39}$. Al ser esto una verdad jurídica-política inocultable, se demuestra que la legislación judicial es ilegítima y, por ende, sin valor jurídico; dicho en otras palabras, sin fuerza vinculante.

Con respecto al cumplimiento de esa legislación judicial, su violación no acarrea ninguna sanción, debido a que el legislador no lo ha contemplado así. La Corte Constitucional, en sentencia de control abstracto de constitucionalidad al peculado, afirmó que contradecir las sentencias de las altas cortes es prevaricar. Este tipo de tentativa de legislación judicial, la cual se realiza a través de sentencias, no es expedida bajo los parámetros de la Constitución Política que la Corte Constitucional debe y dice proteger.

La Corte Constitucional, sobre el precedente, entre otras numerosas sentencias, afirma lo siguiente:

La jurisprudencia de esta Corporación ha sostenido al respecto, que el desconocimiento de precedentes jurisprudenciales puede llevar a la existencia de un defecto sustantivo en una decisión judicial, en la medida en que el respeto al precedente es una obligación de todas las autoridades judiciales, —sea éste vertical u horizontal-, dada su fuerza vinculante y su inescindible relación con la protección de los derechos al debido proceso e igualdad.

PRECEDENTE-Razones de la fuerza vinculante

La fuerza vinculante del precedente en el ordenamiento jurídico colombiano, se explica entonces, al menos, por cuatro razones principales: (i) en virtud del principio de igualdad en la aplicación de la ley (artículo 13 c. P.), que exige tratar de manera igual situaciones sustancialmente iguales; (ii) por razones

39 La Corte Constitucional, la Corte Suprema de Justicia, el Consejo de Estado, el Consejo Superior de la Judicatura, la Fiscalía General de la Nación, los tribunales y los jueces, administran justicia.Véase Constitución Política de Colombia, supra, nota 23. Artículo 116. 
de seguridad jurídica, ya que las decisiones judiciales deben ser "razonablemente previsibles"; (iii) en atención a los principios de buena fe y de confianza legítima (artículo 84 C. P.), que demandan respetar las expectativas generadas por las reglas judiciales en la comunidad; y finalmente, (iv) por razones de rigor judicial, en la medida en que es necesario un mínimo de coherencia en el sistema jurídico.

PRECEDENTE-Definición

Para la Corte Constitucional el precedente, es aquel antecedente del conjunto de sentencias previas al caso que se habrá de resolver, que por su pertinencia para la resolución de un problema jurídico, debe considerar necesariamente un juez o una autoridad determinada, al momento de dictar sentencia ${ }^{40}$.

De esta sentencia se puede colegir confusión conceptual. En el primer inciso afirma que la jurisprudencia ha sostenido la inaplicación del precedente jurisprudencial. El precedente es eso, un precedente, en el cual los operadores jurídicos están obligados a obedecerlo, porque es ley, mientras que para la Constitución Política la jurisprudencia es una figura jurídica que constituye un criterio auxiliar para los jueces.

En otros pronunciamientos, la Corte ha definido el precedente así:

PRECEDENTE CONSTITUCIONAL - Fuerza vinculante / PRECEDENTE CONSTITUCIONAL - Conceptos

En la construcción de la teoría de la obligatoriedad de los precedentes judiciales, la Corte Constitucional ha usado los conceptos de Decisum, ratio decidendi, y obiter dicta, para determinar qué partes de la decisión judicial constituyen fuente formal de derecho. El decisum, la resolución concreta del caso, la determinación de si la norma debe salir o no del ordenamiento jurídico en materia constitucional, tiene efectos erga omnes y fuerza vinculante para todos los operadores jurídicos. La ratio decidendi, entendida como la formulación general del principio, regla o razón general que constituyen la base necesaria de la decisión judicial específica, también tiene fuerza vinculante general. Los obiter dicta o "dichos de paso", no tienen poder vinculante, sino una "fuerza persuasiva" que depende del prestigio y jerarquía del Tribunal, y constituyen criterio auxiliar de interpretación ${ }^{41}$.

40 Véase Corte Constitucional de Colombia. Sentencia T-086 DE 2007 (MP, Manuel Cepeda Espinosa, febrero 8 del 2007).

41 Véase Corte Constitucional de Colombia. Sentencia SU 1330/01 (MP, Marco Monroy Cabra, diciembre 6 del 2001).
Frente a la definición planteada, se afirma que es el conjunto de sentencias previas al caso lo que debe necesariamente considerar la autoridad. Sin embargo, así no es: una sola sentencia establece el precedente. Si se acepta dicha definición, entonces las sentencias de exequibilidad no constituyen precedente judicial, ya que la exequibilidad sobre una ley es por regla general única, de manera que la Corte Constitucional plantea una aporía, en tanto que en su demostración incurre en falacia circular: la conclusión se apoya en una premisa que para ser verdadera depende de que la conclusión también lo sea.

Esto, de una u otra forma genera una tesis que confirma parcialmente lo planteado en esta investigación: no existe fundamento jurídico positivo para el precedente judicial en Colombia, excepto que la jurisprudencia sea norma vinculante con fuerza de ley.

En fin, la Corte Constitucional, para dar cumplimiento a su función, la ha desbordado de forma abultada, ha derogado la Constitución Política y la ha modificado. No se cuenta hasta el momento con una norma que dé existencia jurídica al precedente judicial en Colombia, lógicamente aceptando que la Corte Constitucional carece de competencia funcional para legislar, o no es órgano colegislador con el Congreso de la República. Dado el caso contrario - que se acepte que la rama judicial es colegisladora por delegación constitucional-, el que juzga, legisla (esto es, una tiranía), en cuyo caso sí existe el sustento normativo para el precedente judicial ${ }^{\text {“42 }}$.

\section{Prevaricato Corte Constitucional}

La Corte Constitucional, al judicializar el tipo penal de prevaricato en acción pública de control abstracto de constitucionalidad, afirmó que se incurre en prevaricato al no acoger la interpretación dada por las altas cortes ${ }^{43}$.

De igual forma, afirma la consecuencia positiva de la creación y aceptación ilegítima del precedente judicial, pero no plantea discusión acerca de las consecuencias negativas del precedente, las cuales, en nuestro criterio, son demasiado costosas para la incipiente democracia colombiana: la derogación de hecho de la excepción de inconstitucionalidad, la usurpación de funciones propias de otras ramas del poder público (legislación judicial), la tiranía judicial,

42 Véase Jose Hoyos, Alexander López y Rafael Peréz. Competencia de la Corte Constitucional. Una mirada Desde El PRINCIPIO de legalidad. Precedente JUdicial, SENTENCIAS ADITIVAS y SUSTITUtivas. Editorial Poemia. (2012.).

43 Véase Corte Constitucional de Colombia, supra, nota 31. 


\author{
la derogatoria de la división de poderes ${ }^{44}$ y la tiranía \\ judicial.
}

44 Colombia. CORTe COnstitucional. "8.2. Efectos de los fallos de control de constitucionalidad sobre las leyes.

El artículo 243 constitucional señala que, "los fallos que la Corte dicte en ejercicio del control jurisdiccional hacen tránsito a cosa juzgada constitucional. Ninguna autoridad podrá reproducir el contenido material del acto jurídico declarado inexequible por razones de fondo, mientras subsistan en la Carta las disposiciones que sirvieron para hacer la confrontación entre la norma ordinaria y la Constitución". Véase Constitución Política de Colombia, supra, nota 23. Art. 243. Quiere ello significar que, por mandato constitucional, todas las autoridades públicas en Colombia, incluidos los jueces, deben acatar lo decidido por la Corte en sus fallos de control de constitucionalidad. Ahora bien, en materia de vinculatoriedad de la jurisprudencia constitucional es preciso distinguir, como se ha hecho en otras oportunidades, entre tres componentes del fallo de constitucionalidad: la ratio decidendi, los obiter dictum y el decisum. Al respecto, la Corte en la Sentencia SU-047 de 1999 consideró lo siguiente: "Estos conceptos son formulados de distinta manera y con lenguajes diversos por los autores, lo cual ha generado a veces agudas discusiones conceptuales. Sin embargo, su sentido esencial es relativamente claro: Así, el decisum es la resolución concreta del caso, esto es, la determinación específica de si el acusado es o no culpable en materia penal, si el demandado debe o no responder en materia civil, si al peticionario el juez le tutela o no su derecho, si la disposición acusada es o no retirada del ordenamiento, etc. Por su parte, la ratio decidendi es la formulación general, más allá de las particularidades irrelevantes del caso, del principio, regla o razón general que constituyen la base de la decisión judicial específica. Es, si se quiere, el fundamento normativo directo de la parte resolutiva. En cambio constituye un mero dictum, toda aquella reflexión adelantada por el juez al motivar su fallo, pero que no es necesaria a la decisión, por lo cual son opiniones más o menos incidentales en la argumentación del funcionario". Véase Corte Constitucional de Colombia. Sentencia su 047 (MP, Carlos Gaviria Díaz, Alejandro Martínez Caballero, enero 29 de 1999). En igual sentido, la Corte en la Sentencia C-836 del 2001 se pronunció acerca de las diferencias existentes entre estos tres componentes del fallo de constitucionalidad, en los siguientes términos: "Si la parte de las sentencias que tiene fuerza normativa son los principios y reglas jurídicas, ello significa que no todo el texto de su motivación resulta obligatorio. Para determinar qué parte de la motivación de las sentencias tiene fuerza normativa resulta útil la distinción conceptual que ha hecho en diversas oportunidades esta Corporación entre los llamados obiter dicta o afirmaciones dichas de paso, y los ratione decidendi o fundamentos jurídicos suficientes, que son inescindibles de la decisión sobre un determinado punto de derecho. Sólo estos últimos resultan obligatorios, mientras los obiter dicta, o aquellas afirmaciones que no se relacionan de manera directa y necesaria con la decisión, constituyen criterios auxiliares de la actividad judicial en los términos del inciso $2^{\circ}$ del artículo 230 de la Constitución. Por supuesto, la definición general de dichos elementos no es unívoca, y la distinción entre unos y otros en cada caso no resulta siempre clara. Sin embargo, la identificación, interpretación y formulación de los fundamentos jurídicos inescindibles de una decisión, son labores de interpretación que corresponden a los jueces, y principalmente a las altas Cortes. La ratio decidendi de un caso, por supuesto, no siempre es fácil de extraer de la parte motiva de una sentencia judicial como tal, y por lo tanto, su obligatoriedad no implica la vinculación formal del juez a determinado fragmento de la sentencia descontextualizado de los hechos y de la
La Corte afirma que la excepción de inconstitucionalidad deja de existir cuando ella ya se ha pronunciado sobre una ley en particular. Sin embargo, no tiene en cuenta que ella misma dice que se declare exequible por estos cargos, es decir, que existe la posibilidad de ser inexequible por otros cargos. De igual manera, así haya sido declarada exequible sin la nota de "por estos cargos", ello no es universal; precisamente fue creada la excepción de inconstitucionalidad para situaciones muy especiales, de manera que si el juez encuentra que en el caso particular la ley declarada exequible por la Corte Constitucional, es inexequible para esa persona en esa situación particular, y así deberá declararlo con fundamento en el Artículo 4 y 230 de la Constitución Política. Obviamente, al hacerlo no incurrirá en prevaricato como ilegítimamente y de modo arbitrario lo afirma la Corte Constitucional en esta sentencia:

De igual manera, una vez proferido un fallo de exequibilidad condicionado, al servidor público le está vedado acordarle a la ley un significado distinto de aquel que la Corte consideró que era el único ajustado a la Carta Política.

8.3. Casos en los cuales el desconocimiento de la jurisprudencia sentada por una Alta Corte conlleva, a su vez, una infracción directa de preceptos constitucionales o legales o de un acto administrativo de carácter general.

Existen casos en los cuales un servidor público incurre en el delito de prevaricato por acción, no por desconocer simplemente la jurisprudencia sentada

decisión, aun cuando resulta conveniente que las altas Cortes planteen dichos principios de la manera más adecuada y explícita en el texto de la providencia, sin extender ni limitar su aplicabilidad, desconociendo o sobrevalorando la relevancia material de aquellos aspectos fácticos y jurídicos necesarios para su formulación en cada caso concreto". Véase Corte Constitucional de Colombia. Sentencia C-836 DEL 2001 (MP, Rodrigo Escobar Gil, agosto 9 del 2001).

Así las cosas, una vez proferido un fallo de control de constitucionalidad de una ley ningún juez puede aplicar en una sentencia una norma legal que haya sido declarada inexequible por la Corte Constitucional, so pena de incurrir en delito de prevaricato por acción o por violación directa de la Carta Política, es decir, del artículo 243 Superior. En caso de tratarse de un fallo de exequibilidad, no le sería dable al juez recurrir a la excepción de inconstitucionalidad, en tanto que si se está ante una declaratoria de constitucionalidad condicionada, igualmente le está vedado a cualquier juez acordarle una interpretación distinta a la norma legal que ha sido sometida al control de la Corte, siendo vinculante en estos casos tanto el decisum como la ratio decidendi. De igual manera, la administración pública no puede apartarse de lo decidido por la Corte Constitucional, so pena de incurrir en la mencionada conducta delictiva. 
por una Alta Corte, considerada ésta como una fuente autónoma del derecho, sino porque al apartarse de aquélla se comete, a su vez, una infracción directa de preceptos constitucionales o legales o de un acto administrativo de carácter general.

$\mathrm{Al}$ respecto, cabe señalar que las disposiciones son simples enunciados normativos, cuyo significado sólo es atribuido una vez son interpretados. De allí que de una misma disposición, sea constitucional o legal, pueden derivarse numerosas normas, esto es, mandatos, prohibiciones o permisiones. Así, mientras la primera es el objeto a interpretar, las segundas constituyen el resultado de tal labor.

En tal sentido, se suele afirmar que los preceptos constitucionales son mucho más genéricos que los de las leyes u otras normas. Son, en general, "esquemáticos, abstractos, indeterminados y elásticos", y por lo tanto "no predeterminan por completo en ningún caso el acto de aplicación, sino que éste se produce al amparo de un sistema normativo que abarca diversas posibilidades". No obstante lo anterior, las Constituciones pueden contener disposiciones bien precisas (vgr. la mayoría se alcanza a los 18 años de edad), en tanto que las leyes ordinarias conceptos abiertos o indeterminados (vgr. las buenas costumbres).

En este orden de ideas, se presentan casos en los cuales una disposición ofrece un sentido unívoco, claramente aplicable para la resolución del caso concreto. Se presentaría prácticamente una identidad entre la disposición y norma derivada de ésta, quedando reducida al mínimo la actividad creadora del derecho por parte del juez.

La situación es mucho más compleja cuando por el elevado grado de indeterminación que ofrece una disposición constitucional o legal, su significado no es unívoco ni su aplicabilidad al caso concreto es aceptable por consenso o unanimidad. No se trata por tanto de una fácil labor de subsunción de un supuesto de hecho a lo prescrito en un enunciado normativo sino, en términos de Hesse, de una verdadera tarea de concretización, es decir, de creación judicial de un sistema de normas derivadas que servirán de premisa mayor al momento de resolver un caso concreto.

Así, partiendo de la afirmación según la cual en ciertos casos no existe realmente una mayor diferencia entre la disposición constitucional o legal y la norma derivada de ésta, el acatamiento, por parte de los servidores públicos de los pronunciamientos emanados de las Altas Cortes, equivaldría simplemente a aplicar la ley, con lo cual el debate en torno al carácter vinculante de la jurisprudencia emanada de aquéllas care- cería de toda relevancia. En otras palabras, siendo tan estrecho el nexo existente entre la disposición legal y la norma, la labor de intermediación que cumple la jurisprudencia entre ambas se desvanece, con lo cual la fuerza vinculante termina siendo de la ley y no de aquélla.

Corolario de lo anterior es que cuando los servidores públicos se apartan de la jurisprudencia sentada por las Altas Cortes en casos en los cuales se presenta una simple subsunción, pueden estar incursos en un delito de prevaricato por acción, no por violar la jurisprudencia, sino la Constitución o la ley directamente. La anterior afirmación se ajusta a los dictados del artículo 230 Superior, según el cual los jueces en sus sentencias están sometidos "al imperio de la ley".45

Así, de lo anterior surge la pregunta: ¿Qué es ley? La Corte Constitucional afirma que las sentencias de las altas cortes son normas vinculantes en el sistema jurídico colombiano, a pesar de que la propia Constitución Política afirma de manera clara y categórica que la jurisprudencia es un criterio auxiliar de la administración de justicia, lo que significa que no es ley; no es fuente formal del Derecho, lo es solo y exclusivamente por excepción. Al no ser fuente de Derecho, no es ley; al no ser ley, no es obligatoria, y al no serlo, desobedecerla no implica prevaricar como lo afirma la Corte Constitucional ${ }^{46}$. En el supuesto

45 Véase Corte Constitucional de Colombia, supra, nota 31.

46 En la sentencia se lee: "La situación resulta ser completamente distinta cuando se está ante una disposición constitucional o legal que admite diversos significados, es decir, de aquélla derivan distintas normas jurídicas. En tales situaciones, estima la Corte que la existencia de mecanismos en el ordenamiento jurídico encaminados a controlar jurídicamente a los jueces de inferior jerarquía en el sentido de acatar los precedentes sentados por las Altas Cortes, como lo es el recurso extraordinario de casación, son suficientes para garantizar el carácter vinculante de la jurisprudencia sentada por aquéllas, sin tener que recurrir a una medida tan drástica de intervención en el derecho fundamental de la libertad individual, como lo es un proceso penal por la comisión de un delito de prevaricato por acción. Así mismo, para el caso de los demás servidores públicos no se podría afirmar que, en tales casos, estuvieran actuando de manera "manifiestamente contraria a la ley”. En efecto, en tales situaciones no puede hablarse realmente de una resolución "manifiestamente contraria a la ley", por cuanto, a la luz de la jurisprudencia de la Sala Penal de la Corte Suprema de Justicia, el acto del servidor público o la providencia del juez no resultan ser ostensiblemente arbitrarios o irrazonables. De hecho, suele igualmente suceder que, dado el elevado carácter abierto que ofrece la disposición constitucional o legal, algunas Salas de las Altas Cortes hayan derivado unas normas jurídicas y otras unas distintas, con lo cual ni siquiera se cuente con una jurisprudencia considerada constante en la materia. (...) En este orden de ideas, entender que se puede cometer el delito de prevaricato por acción cuando se está ante casos en los cuales es posible derivar un elevado número de 
que las sentencias de la Corte Constitucional constituyan Derecho, como tal pueden ser objeto de control abstracto de constitucionalidad, opción que la propia Corte Constitucional ha negado. Lo cual resulta una paradoja: crea ley sin control de constitucionalidad, mientras las demás normas sí son objeto de este.

La Corte Constitucional esgrime como sustento jurídico para el precedente la igualdad, la seguridad jurídica y su supremacía. Esta supremacía de la Corte Constitucional - como ya se demostró- no es cierta. En Colombia rige un control de constitucionalidad difuso, por ende, no hay jerarquización entre las autoridades que lo ejercen, más aún en el tema de la acción de tutela: todos los jueces son jueces constitucionales.

Se puede afirmar que la única autoridad judicial que puede declarar que la ley es inexequible es la Corte Constitucional y, por tanto, la única con competencia funcional para ello, de modo que esto la hace la superior. Sin embargo, no es así. El hecho de que la Asamblea Nacional Constituyente le haya delegado esa competencia funcional especial, no implica que en la estructura judicial sea la Corte Constitucional la corte superior de las demás cortes. Al verificar la estructura de la rama judicial no se colige de ella dicha jerarquización, pero sí se evidencia una especialización de las cortes. No existe la jerarquización de las cortes, lo que se plasmó fue una especialización

normas jurídicas, se topa con un grave obstáculo de orden práctico, consistente en la inexistencia en el país de compilaciones actualizadas y asequibles de jurisprudencia de las Altas Cortes. De tal suerte que, a diferencia de lo acontecido con el texto legal, el cual debe ser debidamente promulgado y publicado en el Diario Oficial para ser oponible a los ciudadanos, los fallos proferidos por la jurisdicción ordinaria sólo deben ser notificados a las partes. Ahora bien, la Corte estima que a efectos de determinar si realmente un servidor público, en un caso concreto, incurrió en el delito de prevaricato por acción por desconocimiento de la jurisprudencia sentada por una Alta Corte la cual comporte, a su vez, una infracción directa de preceptos constitucionales o legales o de un acto administrativo de carácter general, resultará indicativo examinar si se está en presencia de un manifiesto alejamiento del operador jurídico de una subregla constitucional constante. En efecto, los fallos de reiteración se caracterizan por que la Corte, (i) simplemente se limita a reafirmar la vigencia de una subregla constitucional perfectamente consolidada; (ii) su número resulta ser extremadamente elevado; y (iii) constituyen interpretaciones constantes y uniformes de la Constitución, la ley o un acto administrativo de carácter general, por parte del juez constitucional. En otras palabras, en los fallos de reiteración la Corte Constitucional ha acordado un sentido claro y unívoco a la "ley", en los términos del artículo 413 del Código Penal. Situación semejante se presenta en las sentencias de unificación jurisprudencial, en la medida en que la Corte acuerde una determinada interpretación no sólo a una disposición constitucional, sino a normas de carácter legal o a un acto administrativo de carácter general". Id. en diversas áreas de competencia: administrativa, ordinaria, militar y constitucional.

\section{E. ¿Existe el precedente judicial en la constitución $y$ la ley colombiana ${ }^{47}$ ?}

De acuerdo con el texto de la Constitución Política $\mathrm{y}$ en la ley vigente, no se encuentra ninguna norma que establezca la obligatoriedad de la jurisprudencia de las altas cortes; es más, la jurisprudencia por definición legal pretende la unificación de la ley para su aplicación.

Hasta este acápite del desarrollo de este artículo no se ha encontrado ninguna norma jurídica expedida por autoridad legítimamente facultada para ello (constituyente primario, legislador), que establezca el precedente judicial. Al respecto, el profesor Bernal afirma:

En Colombia, sin embargo, la atribución de fuerza vinculante a la jurisprudencia Constitucional, es decir, el reconocimiento del precedente Constitucional, y la correlativa sujeción a esta fuente de derecho por parte de todos los poderes del Estado y de los particulares, no ha tenido un reconocimiento claro y explícito en ningún texto Constitucional ni legal ${ }^{48}$.

En la cita anterior del prestigioso profesor Bernal, se manifiesta de manera pálida la inexistencia de un sustento normativo para la legitimidad del precedente. Por otro lado, lo afirmado genera una clara contradicción, cuando dice: "el reconocimiento del precedente Constitucional, y la correlativa sujeción a esta fuente de derecho por parte de todos los

$47 \mathrm{Al}$ respecto, Reyes Echandia, ALDANA ROZO LUIS ENRIQUE, GOMEZ, FABIO ALVARO, CALDERON BOTERO LUNA,.. Afirman: "Si bien es verdad que la mayoría de las instituciones jurídicas tienen un alcance universal, por lo menos uniformes dentro de sistemas jurídicos afines, no menos cierto es que el alcance y sentido de algunos puntos en particular están determinados por peculiaridades de la legislación que tiene un ámbito de aplicación restringido al territorio donde ella impera. En otras palabras, es la normatividad vigente el necesario punto de partida para la respuesta a los problemas en particular y, en consecuencia, toda modificación legislativa puede traer distintos modos de resolverlos, con los obvios distanciamientos o aproximaciones a las soluciones que a esos problemas se da en ordenamientos que rigen otras latitudes." Salvamento de voto. Véase Alfonso Reyes Echandia, Aldana Rozo Luis Enrique, Gómez Fabio Álvaro y Calderon BOTERO Luna. Título del artículo. JURISPRUdencia y doctrina XIII,150. Fecha. Pág.

48 Véase Carlos Bernal Pulido. El DeRecho de los Derechos. Editorial Universidad Externado de Colombia. (2008). Pág. 109. 
poderes del Estado"49. Si la jurisprudencia es fuente de Derecho, entonces es vinculante, por ende, será precedente. Se colige que acepta la confusión conceptual entre precedente y jurisprudencia, planteada por la Corte Constitucional.

La respuesta debe ser categórica: en el sistema jurídico colombiano no existe sustento normativo de carácter constitucional para el precedente judicial. La ley no ha definido el precedente judicial, mientras que si ha definido de manera clara qué es jurisprudencia, sus efectos, quién la expide, cuándo surge, en fin, la ley se ha ocupado de la jurisprudencia. No obstante, frente al precedente no se menciona siquiera esta figura jurídica hasta el Código de Procedimiento Administrativo y de lo Contencioso Administrativo (CPACA) para las sentencias de unificación.

La Ley 1437 del 2011, en el Artículo 10, establece el reconocimiento y aplicación de la jurisprudencia del Consejo de Estado (precedente judicial) y lo hace en los siguientes términos:

Artículo 10: Deber de aplicación uniforme de las normas y la jurisprudencia. $\mathrm{Al}$ resolver los asuntos de su competencia, las autoridades aplicarán las disposiciones constitucionales, legales y reglamentarias de manera uniforme a situaciones que tengan los mismos supuestos fácticos y jurídicos. Con este propósito, al adoptar las decisiones de su competencia, deberán tener en cuenta las sentencias de unificación jurisprudencial del Consejo de Estado en las que se interpreten y apliquen dichas normas ${ }^{50}$.

Es evidente que hablan de la fuerza vinculante de la jurisprudencia, derogan lo pertinente de la jurisprudencia para la justicia contenciosa administrativa, pero igualmente no lo denominaron precedente judicial.

El Artículo 102 de la Ley 1437 de 2011, establece la "extensión de la jurisprudencia del Consejo de Estado a terceros por parte de las autoridades, en esta norma se lee: "Las autoridades deberán extender los efectos de una sentencia de unificación jurisprudencial dictada por el Consejo de Estado, en la que se haya reconocido un derecho, a quienes lo soliciten y acrediten los mismos supuestos fácticos y jurídicos" ${ }^{\prime 1}$.

El Congreso de la República, a través de la Ley 1437 del 2011, ha creado el precedente judicial para

49 Id.

50 Véase Ley 1437 de 2011. Por la cual se expide el Código de Procedimiento Administrativo y de lo Contencioso Administrativo. Enero 18 del 2011. Do N. ${ }^{\circ} 47.956$.

51 Id. la rama contenciosa administrativa. Las sentencias de unificación jurisprudencial del Consejo de Estado son obligatorias para todas las autoridades, inclusive la judicial. De acuerdo al tenor de esta ley, las sentencias de unificación jurisprudencial exclusivamente constituyen precedente judicial, y son vinculantes para todas las autoridades del país. Como conclusión, se puede decir que no existe sustento normativo alguno para el precedente judicial constitucional creado por la Corte Constitucional.

A partir de julio del 2012, en Colombia existe jurídicamente la aplicación de la jurisprudencia con carácter vinculante, una aproximación legislativa al precedente judicial en lo contencioso administrativo, a través de las sentencias de unificación jurisprudencial del Consejo de Estado.

$\mathrm{Al}$ aclarar que el legislador guardó silencio sobre qué es lo vinculante de las sentencias de unificación de jurisprudencia, debemos remitirnos a la ley: al Artículo 17 del Código Civil, norma que establece que la parte vinculante es la resolutiva. Sin embargo, la parte resolutiva de las sentencias tienen su fundamento en la motivación del fallo, y como ya se dijo, la sentencia es un solo cuerpo, de modo que será vinculante el todo, es decir, la sentencia como tal, ya que el fallo por regla general es coherente con las razones planteadas.

La Corte Constitucional, a través de sus sentencias de control abstracto, modificó la Constitución Política, en especial el Artículo 150. Ahora, dicha norma debe leerse: "hacen parte de la rama legislativa el Congreso de la República yla Corte Constitucional"; estamos ante una tiranía, dos poderes en un solo órgano estatal.

Se probó que la Corte Constitucional carece de la competencia funcional para legislar. A pesar de ello, lo hace de manera abierta, contrariando y violando de manera flagrante las competencias funcionales otorgadas por la Constitución Política a los diferentes órganos estatales, a través de las sentencias aditivas y sustitutivas. Esto es usurpación de competencias funcionales constitucionales. Esta situación fáctica derogó la división de poderes, de manera que la Corte Constitucional abrogó funciones legislativas que la Constitución Política no le otorgó.

Se alcanzó a demostrar que, constitucional y legalmente (normativamente), el sustento normativo del precedente judicial en el sistema jurídico de Colombia no existe ${ }^{52}$. Aceptar que el precedente tiene

52 Excepto en el nuevo Código Contencioso Administrativo, que rige a partir de julio del 2012.

${ }^{(* *)}$ Se utilizó la palabra justificar y no legitimar, adrede, con 
su origen en nuestro país a partir de las sentencias de los jueces, es desconocer el principio de legalidad, es decir, es ir en contra de lo ordenado en la Constitución Política y la ley vigente.

Está probado, de conformidad con el marco normativo vigente, que el precedente judicial como institución jurídica- no existe en Colombia; más aún, la propia Constitución Política establece que la jurisprudencia constituye un criterio auxiliar, además, ni en ella ni en la ley se plasma el concepto de precedente como norma vinculante (ni siquiera se nombra).

Se demostró que sobre lo ordenado en las sentencias aditivas y sustitutivas, se entiende que la Corte Constitucional derogó los Artículos 4 y 230, entre otros, en tanto que los jueces no pueden aplicar la excepción de inconstitucionalidad, sino es bajo la égida interpretativa dada por ella a la ley y a la Constitución ${ }^{53}$.

Siguiendo la Constitución Política, se tiene el principio de legalidad, establecido en el Artículo $29^{54}$, el cual, en concordancia con el Artículo 4 de la misma, rige sobre la ley.

la intención de llamar la atención o hacer énfasis en la situación ilegitima en la que estamos absortos, la que es aceptada por los abogados, sociólogos, politólogos, en donde la institucionalidad que se legitima por la Constitución Política y la ley deja de ser el referente y pasa a serlo, una institución. Se acepta que en nombre de la Constitución Política esta sea modificada, acomodada, a las exigencias de unos jueces que juraron guardarla y cumplirla, y para hacerlo la derogan, la modifican, la adicionan, la sustituyen sin legitimidad alguna. Pero lo peor, no es esta situación sino la aceptación de ello por la sociedad entera. (casi nosotros no).

53 Se afirma que los jueces de la República pueden apartarse de un precedente siempre y cuando sustenten las razones de ello; lo que es posible en A.T., pero si se trata de la aplicación de una ley que ya fue objeto de control constitucional y fue declarada exequible. La Corte Constitucional es la última palabra en este tema, (según ella, no el sistema jurídico), y dicha sentencia es general y abstracta, vinculante, no queda alternativa. Para la mayoría de los casos los jueces no darán aplicación a la excepción de inconstitucionalidad, más aún cuando con ello podría prevaricar.

54 "El debido proceso se aplicará a toda clase de actuaciones judiciales y administrativas. Nadie podrá ser juzgado sino conforme a leyes preexistentes al acto que se le imputa, ante juez o tribunal competente y con observancia de la plenitud de las formas propias de cada juicio.En materia penal, la ley permisiva o favorable, aun cuando sea posterior, se aplicará de preferencia a la restrictiva o desfavorable. Toda persona se presume inocente mientras no se la haya declarado judicialmente culpable. Quien sea sindicado tiene derecho a la defensa y a la asistencia de un abogado escogido por él, o de oficio, durante la investigación y el juzgamiento; a un debido proceso público sin dilaciones injustificadas; a presentar pruebas y a controvertir las que se alleguen en su contra; a impugnar la sentencia condenatoria, y a no ser juzgado dos veces por el mismo hecho. Es nula, de pleno derecho, la prueba obtenida con violación del debido proceso". Véase Constitución Política de Colombia, supra, nota 23. ArtÍculo 29.
El legislador, en la Ley 599, determinó el tipo penal denominado "prevaricato" y describió la conducta sancionable así:

Artículo 413. Prevaricato por acción. Modificado por el art. 33, Ley 1474 de 2011. El servidor público que profiera resolución, dictamen o concepto manifiestamente contrario a la ley, incurrirá en prisión de tres (3) a ocho (8) años, multa de cincuenta (50) a doscientos (200) salarios mínimos legales mensuales vigentes, e inhabilitación para el ejercicio de derechos y funciones públicas de cinco (5) a ocho (8) años. Declarado Exequible Sentencia Corte Constitucional 917 de $2001^{55}$.

El tipo penal determinó que toda resolución, dictamen o concepto manifiestamente contrario a la ley, lo que significaba según la interpretación gramatical de la norma, misma que la Corte Constitucional ha aceptado como una forma valida de interpretación de la ley.

La Corte Constitucional, en la Sentencia C-917 del 2001, afirma:

b) En cuanto al prevaricato por acción descrito como conducta delictual tanto en el artículo 149 del Código Penal anterior, como en el artículo 413 del la Ley 599 de 2000, encuentra la Corte que la conducta está descrita de manera inequívoca por el legislador, pero ella requiere que se haya proferido una resolución, dictamen o concepto que resulte contrario a la ley, de manera manifiesta, lo que indica claramente que esa conducta constitutiva de delito tiene como referente necesario a la ley [cursivas añadidas], en cada caso concreto, para comparar, luego, la actuación del servidor público al emitir la resolución, dictamen o concepto, de lo que podrá concluirse, por parte del funcionario penal competente, si se ajustó a la ley, o si la quebrantó, y si esa violación, en caso de existir, resulta manifiesta, es decir, ostensible ${ }^{56}$.

Sobre este punto, es pertinente transcribir un aparte de una sentencia reciente de la Corte Suprema de Justicia en la que analizó el contenido del Artículo 146 del Código Penal, y señaló que la conducta juzgada objetivamente es típica. Para ello, partió del examen de los artículos constitucionales y legales a

55 Véase Ley 599 del 2000. Por la cual se expide el Código Penal. Do N. ${ }^{\circ} 44097$. Julio 24 del 2000.

56 Véase Corte Constitucional de Colombia. Sentencia C-917/01. (MP Alfredo Beltrán Sierra, Agosto 29 del 2001). 
los que remite la disposición, y resumió el resultado del estudio así:

La conclusión, entonces, es obvia: dentro de la definición del artículo 146 del Código Penal, están materialmente incorporados también como componentes suyos y por encima de los demás, los principios constitucionales y legales de la contratación, en el entendido que las exigencias esenciales de los trámites, las celebraciones y las liquidaciones de los contratos de la administración devienen y se impregnan en todo momento de esos axiomas ${ }^{57}$.

No puede, entonces, aceptarse la acusación de vaguedad e imprecisión, lo cual resultaría en desmedro de la garantía de legalidad. Por el contrario, ha de concluirse que, a diferencia de lo sostenido por el demandante, esa garantía de la descripción del delito de prevaricato por acción, sí se ha cumplido a plenitud. En lo esencial, la conducta objeto del reproche jurídico penal ha sido descrita por la ley. Es decir, lo que constituye el propio núcleo de la conducta delictiva es conocida por los destinatarios de la ley penal y por los funcionarios encargados de aplicarla, al igual que las sanciones respectivas fueron previstas para cada uno de estos delitos por la ley.

Obsérvese, entonces, que respecto de las normas acusadas como presuntamente inconstitucionales, el principio de legalidad, en cuanto exige que no pueda existir delito sin ley que lo defina, ni pena sin ley que la determine, no ha sido desconocido en este caso por el legislador.

Se infiere del contenido de esta sentencia que la Corte Constitucional reconoce como acorde con la Constitución Política vigente la norma del Código Penal denominada "Prevaricato", en el sentido que viole la ley; por ley se entiende las normas jurídicas expedidas por el legislador, sancionadas y publicadas por el ejecutivo.

En el año 2008, la misma Corte Constitucional, en la Sentencia C-335/08 sobre el prevaricato, afirma:

PREVARICATO - Configuración por vulneración de ley procesal o trasgresión de preceptos constitucionales / PREVARICATO -Conducta sólo puede ser cometida por sujeto activo cualificado.

En escasas ocasiones, la Corte Constitucional se ha pronunciado en relación con el delito de prevaricato. Así, en sentencia T-118 de 1995 consideró que una

57 Véase Corte Suprema de Justicia. SAla de Casación Penal. Proceso 17088. (MP José María Esguerra, diciembre 19 del 2000). abierta contradicción de preceptos constitucionales por parte de un funcionario público daba lugar a una investigación penal por el delito de prevaricato. De la misma manera en sentencia T- 260 de 1999 se refirió a la conducta de prevaricato indicando que la misma exigía tener en cuenta la condición del agente, por cuanto dicha conducta sólo puede ser cometida por un sujeto activo cualificado.

PREVARICATO POR ACCION EN JURISPRUDENCIA DE LA SALA PENAL DE LA CORTE SUPREMA DE JUSTICIA - Elementos que configuran el tipo penal

En relación con la configuración del tipo penal de prevaricato por acción, la jurisprudencia sentada por la Corte Suprema de Justicia, ha considerado que: (i) el delito puede ser cometido por los jueces, los servidores públicos y en ocasiones por particulares que ejercen funciones públicas, en los términos que señala el Código Penal; (ii) en cuanto al sujeto pasivo de la conducta, se ha estimado que es la administración pública, aunque se admite que, en ciertos casos, pueda tratarse de un delito pluriofensivo como cuando con aquél se vulneran igualmente bienes jurídicos de los particulares; (iii) el objeto material del delito comprende resoluciones, dictámenes o conceptos, es decir, abarca tanto decisiones judiciales como actos administrativos. A su vez, la expresión "contrario a la ley", ha sido entendida por la Sala Penal de la Corte Suprema de Justicia, en el sentido de que con aquélla se designa: (i) la norma jurídica aplicable al caso concreto; (ii) el ordenamiento jurídico colombiano; (iii) los mandatos constitucionales; (iv) ley en sentidos formal y material, ya que no distingue entre una y otra; y (v) actos administrativos. En otras palabras, de conformidad con la jurisprudencia sentada por la Sala Penal de la Corte Suprema de Justicia, la expresión "ley", contenida en el artículo 413 del Código Penal no ha sido entendida como norma jurídica aplicable al caso concreto, interpretación que es plausible y ajustada a la Constitución.

PRINCIPIO DE LEGALIDAD EN MATERIA PENAL - Principios que debe acatar el legislador al momento de tipificar un delito

El principio de legalidad en materia penal comporta que el legislador, al momento de tipificar un delito y fijar la correspondiente pena acate los siguientes principios: (i) La prohibición de la analogía (nullum crimen, nulla poena sine lege stricta); (ii) la prohibición del derecho consuetudinario para fundamentar y agravar la pena (nullum crimen, nulla poena sine lege scripta); (iii) la prohibición de la retroactividad (nullum crimen, nulla poena sine lege praevia); (iv) 
la prohibición de delitos y penas indeterminados (nullum crimen, nulla poena sine lege certa); (v) el principio de lesividad del acto (nulla lex poenalis sine iniuria); (vi) el principio de la necesidad de tipificar un comportamiento como delito (nullum crimen sine necessitate); y (vii) el derecho penal de acto y no de autor.

DELITO DE PREVARICATO POR ACCIÓN - Se comete cuando la disconformidad se encuentre frente a fallos de constitucionalidad o por desconocimiento de jurisprudencia que conlleve la infracción directa de preceptos constitucionales o legales

El delito de prevaricato por acción no se comete por una simple disconformidad que se presente entre una providencia, resolución, dictamen o concepto y la jurisprudencia proferida por las Altas Cortes, a menos que se trate de un fallo de control de constitucionalidad de las leyes o de la jurisprudencia sentada por aquéllas que comporte una infracción directa de preceptos constitucionales, legales o de un acto administrativo de carácter general.

JURISPRUDENCIA DE ALTAS CORTES - Carácter vinculante redunda en la coherencia del sistema jurídico y garantiza la vigencia del derecho a la igualdad

Reconocerle fuerza vinculante a la jurisprudencia sentada por la Corte Constitucional, la Corte Suprema de Justicia, el Consejo de Estado y la Sala Disciplinaria del Consejo Superior de la Judicatura, redunda en una mayor coherencia del sistema jurídico colombiano, lo cual no se contradice con imperativos de adaptación a los cambios sociales y económicos. De igual manera, la vinculatoriedad de los precedentes garantiza de mejor manera la vigencia del derecho a la igualdad ante la ley de los ciudadanos, por cuanto casos semejantes son fallados de igual manera. Así mismo, la sumisión de los jueces ordinarios a los precedentes sentados por las Altas Cortes asegura una mayor seguridad jurídica para el tráfico jurídico entre los particulares.

PREVARICATO POR ACCIÓN - Configuración por desconocimiento de la jurisprudencia de una alta corte Existen casos en los cuales un servidor público incurre en el delito de prevaricato por acción, no por desconocer simplemente la jurisprudencia sentada por una Alta Corte, considerada ésta como una fuente autónoma del derecho, sino porque al apartarse de aquélla se comete, a su vez, una infracción directa de preceptos constitucionales o legales o de un acto administrativo de carácter general ${ }^{58}$.
Existen casos en los cuales un servidor público incurre en el delito de prevaricato por acción, no por desconocer simplemente la jurisprudencia sentada por una alta corte, considerada esta como una fuente autónoma del Derecho, sino porque al apartarse de aquélla se comete, a su vez, una infracción directa de preceptos constitucionales o legales o de un acto administrativo de carácter general, es decir, la interpretación realizada por la alta corte.

Al respecto, cabe señalar que las disposiciones son simples enunciados normativos, cuyo significado solo es atribuido una vez son interpretados. De allí que de una misma disposición, sea constitucional o legal, pueden derivarse numerosas normas, esto es, mandatos, prohibiciones o permisiones.

Así, mientras la primera es el objeto a interpretar, las segundas constituyen el resultado de tal labor.

En tal sentido, se suele afirmar que los preceptos constitucionales son mucho más genéricos que los de las leyes u otras normas. Son, en general, "esquemáticos, abstractos, indeterminados y elásticos", y por lo tanto "no predeterminan por completo en ningún caso el acto de aplicación, sino que éste se produce al amparo de un sistema normativo que abarca diversas posibilidades". No obstante lo anterior, las Constituciones pueden contener disposiciones bien precisas (vgr. la mayoría se alcanza a los 18 años de edad), en tanto que las leyes ordinarias conceptos abiertos o indeterminados (vgr. las buenas costumbres).

En este orden de ideas, se presentan casos en los cuales una disposición ofrece un sentido unívoco, claramente aplicable para la resolución del caso concreto. Se presentaría prácticamente una identidad entre la disposición y norma derivada de ésta, quedando reducida al mínimo la actividad creadora del derecho por parte del juez.

La situación es mucho más compleja cuando por el elevado grado de indeterminación que ofrece una disposición constitucional o legal, su significado no es unívoco ni su aplicabilidad al caso concreto es aceptable por consenso o unanimidad. No se trata por tanto de una fácil labor de subsunción de un supuesto de hecho a lo prescrito en un enunciado normativo sino, en términos de Hesse, de una verdadera tarea de concretización, es decir, de creación judicial de un sistema de normas derivadas que servirán de premisa mayor al momento de resolver un caso concreto. (....) Corolario de lo anterior es que cuando los servidores públicos se apartan de la jurisprudencia sentada por las Altas Cortes en casos en los cuales se presenta una simple subsunción, pueden estar incursos en un de- 
lito de prevaricato por acción, no por violar la jurisprudencia, sino la Constitución o la ley directamente. La anterior afirmación se ajusta a los dictados del artículo 230 Superior, según el cual los jueces en sus sentencias están sometidos "al imperio de la ley". (...)

En este orden de ideas, entender que se puede cometer el delito de prevaricato por acción cuando se está ante casos en los cuales es posible derivar un elevado número de normas jurídicas, se topa con un grave obstáculo de orden práctico, consistente en la inexistencia en el país de compilaciones actualizadas y asequibles de jurisprudencia de las Altas Cortes. De tal suerte que, a diferencia de lo acontecido con el texto legal, el cual debe ser debidamente promulgado y publicado en el Diario Oficial para ser oponible a los ciudadanos, los fallos proferidos por la jurisdicción ordinaria sólo deben ser notificados a las partes.

Ahora bien, la Corte estima que a efectos de determinar si realmente un servidor público, en un caso concreto, incurrió en el delito de prevaricato por acción por desconocimiento de la jurisprudencia sentada por una Alta Corte la cual comporte, a su vez, una infracción directa de preceptos constitucionales o legales o de un acto administrativo de carácter general, resultará indicativo examinar si se está en presencia de un manifiesto alejamiento del operador jurídico de una subregla constitucional constante.

En efecto, los fallos de reiteración se caracterizan por que la Corte (i) simplemente se limita a reafirmar la vigencia de una subregla constitucional perfectamente consolidada; (ii) su número resulta ser extremadamente elevado; y (iii) constituyen interpretaciones constantes y uniformes de la Constitución, la ley o un acto administrativo de carácter general, por parte del juez constitucional. En otras palabras, en los fallos de reiteración la Corte Constitucional ha acordado un sentido claro y unívoco a la "ley", en los términos del artículo 413 del Código Penal. Situación semejante se presenta en las sentencias de unificación jurisprudencial, en la medida en que la Corte acuerde una determinada interpretación no sólo a una disposición constitucional, sino a normas de carácter legal o a un acto administrativo de carácter general ${ }^{59}$.

De esta manera, la Corte Constitucional, en clara y arbitraria manifestación de poder, crea el delito de prevaricato por violación a las decisiones reiteradas de las altas cortes de Colombia. Así, entonces, ¿̇urge un vacío normativo o subrogación del marco normativo, con el cambio de jurisprudencia? ¿Aplica

$59 \quad I d$. el principio de favorabilidad? El legislador judicial guardó silencio.

La Sala Penal de la Corte Suprema de Justicia, sobre el prevaricato por conculcar la jurisprudencia, denominada ahora como precedente judicial, afirma:

Las decisiones de las altas Cortes son fuente formal de derecho - para el caso del Derecho Penal—, pues crean reglas jurídicas acerca de cómo debe interpretarse el ordenamiento, naturaleza que las dota de fuerza vinculante, esto es, del deber de acatamiento por parte de los jueces, sin que se desconozcan los principios de autonomía e independencia, pues de todas formas, por tratarse de un sistema flexible del precedente, existe la posibilidad de apartarse de éste, más no de cualquier manera, de forma arbitraria y sin ningún esfuerzo dialéctico, sino siempre que se cumpla con la carga argumentativa. En consecuencia, comete el delito de prevaricato por acción el Juez que desconoce los precedentes jurisprudenciales emanados de la Sala de Casación Laboral de la Corte Suprema de Justicia ${ }^{60}$.

En la misma sentencia se afirma lo siguiente:

Este tipo penal se encuentra constituido por tres elementos, a saber: un sujeto activo calificado, es decir, que se trate de servidor público; que ese funcionario profiera resolución o dictamen; y que éste sea manifiestamente contrario a la ley [cursivas añadidas].

En torno a la estructura del prevaricato y cómo se establece la contrariedad manifiesta de una decisión con la ley, la Corte ha dicho: "La resolución, dictamen o concepto que es contrario a la ley de manera manifiesta, es aquella que de su contenido se infiere sin dificultad alguna la falta de sindéresis y de todo fundamento para juzgar los supuestos fácticos y jurídicos de un asunto sometido a su conocimiento, no por la incapacidad del servidor público y si por la evidente, ostensible y notoria actitud suya por apartarse de la norma jurídica que lo regula."

"La conceptualización de la contrariedad manifiesta de la resolución con la ley hace relación entonces a las decisiones que sin ninguna reflexión o con ellas ofrecen conclusiones opuestas a lo que muestran las pruebas o al derecho bajo el cual debe resolverse el asunto, de tal suerte que el reconocimiento que se haga resulta arbitrario y caprichoso al provenir de una delibera-

60 Véase Corte Suprema de Justicia. Sala de Casación Penal. ACTA N. ${ }^{\circ}$ 106, RAdiCADo 39456. (MP José Luis Barceló Camacho, abril 10 del 2013). 
da y mal intencionada voluntad del servidor público por contravenir el ordenamiento jurídico."

"En consecuencia, no caben en ella las simples diferencias de criterios respecto de un determinado punto de derecho, especialmente frente a materias que por su enorme complejidad o por su misma ambigüedad admiten diversas interpretaciones u opiniones, pues no puede ignorarse que en el universo jurídico suelen ser comunes las discrepancias aun en temas que aparentemente no ofrecerían dificultad alguna en su resolución."

"Como tampoco la disparidad o controversia en la apreciación de los medios de convicción puede ser erigida en motivo de contrariedad, mientras su valoración no desconozca de manera grave y manifiesta las reglas que nutren la sana crítica, pues no debe olvidarse que la persuasión racional elemento esencial de ella permite al juzgador una libertad relativa en esa labor, contraria e inexistente en un sistema de tarifa legal."

"Sin embargo, riñen con la libertad relativa la apreciación torcida y parcializada de los medios probatorios, su falta de valoración o la omisión de los oportuna y legalmente incorporados a una actuación, en consideración a que por su importancia probatoria justificarían o acreditarían la decisión en uno $\mathrm{u}$ otro sentido a partir del mérito suasorio que se les diera o que hubiera podido otorgárseles"61.

La sala penal de la Corte Suprema de Justicia (CSJ), en la determinación de los elementos del tipo, no menciona a la jurisprudencia como parte de la ley, es decir, juzga el apartarse de la jurisprudencia de un juez incurre en la descripción típica de Prevaricato.

La sala penal de la csj realiza dicho juzgamiento con la falacia ad verecundiam, lo cual confirma el error lógico y jurídico de la similitud o igualación de la jurisprudencia a la ley.

\section{CONCLUSIONES}

- La legislación judicial se constituye en violación directa de la Constitución Política, ergo, es prevaricato.

- El prevaricato solo es posible en su adecuación típica por violación a la ley.

- Se incurre en prevaricato al juzgar a un servidor público por expedir resolución o dictamen contrario a la jurisprudencia de las altas cortes.
- El prevaricato por violación a la jurisprudencia implica negar el cambio de jurisprudencia o, por lo menos, que estos cambios no fueran mediáticos ( dependiendo del nivel social del implicado).

\section{ReFERENCIAS}

Alfonso Reyes-Echandia, Luis Enrique Aldana Rozo, Fabio Álvaro Gómez y Luna Calderón-Botero. Título del artículo. JuRisprudencia y Doctrina XiII, 150. Fecha. Pág.

Barón de Montesquieu. Del espíritu de las leyes. Editorial Tecnos s. A. (1985).

Carl Schmitt. La Defensa de la Constitución. Estudio ACERCA DE LAS DIVERSAS ESPECIES Y POSIBILIDADES DE SALVAGUARDA DE LA CONSTitución. (1931). Editorial Labor S.A.

Carlos Bernal-Pulido. El derecho de los Derechos. Editorial Universidad Externado de Colombia. (2008).

Código Civil Colombiano [CCC]. Editorial Legis s. A. (2009).

Corte Constitucional. Sentencia C-037 DE 1996 (MP, Vladimiro Naranjo Mesa, mayo 2 de 1996).

Corte Constitucional de Colombia. Sentencia su 047 (MP, Carlos Gaviria Díaz, Alejandro Martínez Caballero, enero 29 de 1999)

Corte Constitucional de Colombia. Sentencia C-252/o1 (MP, Carlos Gaviria Díaz, febrero 28 del 2001).

Corte Constitucional de Colombia. Sentencia C-836/o1 (MP, Rodrigo Escobar Gil, agosto 9 del 2001).

Corte Constitucional de Colombia. Sentencia C-917/01 (MP, Alfredo Beltrán Sierra, Agosto 29 del 2001).

Corte Constitucional de Colombia. Sentencia SU-1330/01 (MP Marco Monroy Cabra, diciembre 6 del 2001).

Corte Constitucional de Colombia. Sentencia T-086/07 (MP, Manuel Cepeda Espinosa, febrero 8 del 2007).

Corte Suprema de Justicia. Sala de Casación Penal. ProCESO 17088. (MP, José María Esguerra, diciembre 19 del 2000).

Corte Suprema de Justicia. Sala de Casación Penal. RaDICADO: 39456. (MP, José Luis Barceló Camacho, abril 10 del 2013).

Hans Kelsen. Teoría Pura del Derecho. Editorial Porrúa. (2009).

Jose Hoyos, Alexander López y Rafael Peréz. Competencia DE la Corte Constitucional. Una Mirada desde EL PRINCIPIO DE Legalidad. Precedente JUdicial, SENTENCIAS ADITIVAS Y SUSTITUtivas. Editorial Poemia. (2012.). 
Ley 153 de 1887. Por la cual se adiciona y reforman los códigos nacionales, la ley 61 de 1886 y la 57 de 1887 . Agosto 28 de 1998. Do N. ${ }^{\circ} 7151$ y 7152.

Ley 599 del 2000. Por la cual se expide el Código Penal. Do N. ${ }^{\circ} 44097$. Julio 24 del 2000.

Ley 1437 de 2011. Por la cual se expide el Código de Procedimiento Administrativo y de lo Contencioso Administrativo. Enero 18 del 2011. DO N. ${ }^{\circ} 47.956$.
Pierre Bourdieu y Gunther Teubner. La racionalidad jurídica en crisis. Editorial Siglo del Hombre, Ediciones Uniandes, Instituto Pensar. (2000).

Wilson Herrera-Llanos. La rama legislativa del poder público en Colombia. Revista de DeRecho 20. 2003. Págs. 363-406. 